\title{
Local Fiscal Policies and Urban Wage Structures
}

\author{
Patricia Beeson \\ Department of Economics, University of Pittsburgh \\ Lara Shore-Sheppard \\ Department of Economics, Williams College \\ and NBER \\ Tara Watson+ \\ Department of Economics, Williams College \\ and NBER
}

April 2010

+Corresponding author: Tara.Watson@williams.edu, Department of Economics, South Academic Building, 24 Hopkins Hall Drive, Williams College, Williamstown, MA 01267. 


\begin{abstract}
It has long been recognized that average wages vary strikingly across regions and urban areas, in part due to differences in local amenities and fiscal policies. However, analogous differences in wage dispersion remain relatively unexplored. We develop a model suggesting that, after accounting for individual characteristics, wage dispersion across income groups should reflect differences in the relative valuation of local amenities and fiscal policies. We empirically investigate whether there is a link between local taxes and expenditures and the degree of dispersion in the wage structure, and find evidence that such a relationship exists.
\end{abstract}

Keywords: inequality, wage distributions, local expenditures, local taxes JEL: H7, J31 


\section{Introduction}

It is well established that wage inequality rose in the United States in the last quarter of the twentieth century. Less commonly studied is how inequality differs across urban areas. This is somewhat surprising given the long literature exploring how average wages vary across cities (see, for example, Hanushek (1973), Sahling and Smith (1983), and Farber and Newman (1987)). Little is known about the nature of the variation in wage distributions across cities or why such variation exists.

Figure 1, which displays kernel estimates of the density of log hourly wages for 10 cities using data from the 2000 Census, provides simple illustrative evidence that wage distributions differ across cities. ${ }^{1}$ Some cities, such as Minneapolis and Seattle, have relatively "tight" distributions, while others, such as Los Angeles and Houston, have distributions which are relatively more spread. The distributions also differ in their shape, with some having relatively more mass at the lower end (Atlanta and Pittsburgh) and others having relatively more mass at the upper end (New York and Boston).

Previous studies of interurban differences in wage structures have tended to focus on sources of short-run differences in wage distributions, such as those caused by changes in the relative demand or supply of workers with different skills in some regions (see, for example, Borjas and Ramey (1995), Bartik (1996), Cloutier (1997), Levernier, Rickman and Partridge (1998), McCall (2000), Reed (2001), Wheeler (2004)). An increase in the demand for high-skill labor in one city, or an influx of low-skill immigrants to another, can temporarily cause increases in wage dispersion in the affected city relative to other cities. Over time, however, migration of workers to the areas where their return is the highest should theoretically eliminate these transitory differences in wage distributions.

Other recent empirical work explores determinants of inequality that might be expected to generate permanent differences in the distribution of wages. Volscho and Fullerton (2005) find that union density and government sector employment reduce earnings inequality in metropolitan areas, for example.

\footnotetext{
${ }^{1}$ The kernel densities are estimated using an Epanechnikov kernel with the bandwidth selected to minimize the mean integrated squared error. Note that due to top-coding in the data, wage dispersion in the upper tail of the distribution may be understated.
} 
Sanchez (2002) explores the link between inequality and public transit. Moretti (2008) notes that college graduates are increasingly concentrated in more expensive metropolitan areas, and attributes this trend partially to productivity differences. This recent literature raises the question of whether and how metropolitan area characteristics affect wage dispersion.

In the empirical work below, we document that between 1980 and 2000 wage inequality changed very little across metropolitan areas - that is, metropolitan areas that were more unequal in 1980 also tended to be more unequal in 2000. These differences are evident even after controlling for worker characteristics, suggesting that characteristics of metropolitan areas themselves are leading to long-run differences in wage dispersion across cities.

The urban literature on local amenities and fiscal structures offers a reason why we might expect permanent differences in wages across metropolitan areas beyond those related to worker characteristics. Roback (1982) offers a classic model positing that marginal utility of workers must be equalized across areas in a world of perfect mobility; in the presence of heterogeneous metropolitan area characteristics the adjustments of wages and rents across cities act to equalize worker utility. Fiscal structures in particular have been identified as determinants of average wages between cities because of compensating wage differentials (Gyourko and Tracy 1989) - workers are willing to live in a metropolitan area with favorable fiscal characteristics despite lower average nominal wages. These differences are not expected to disappear over time because they reflect the fact that metropolitan characteristics equalize utility (rather than wages) for the marginal worker. Using a similar model, Helms (1985) argues that taxes and expenditures can enhance or dampen economic growth, in part because of the migration of workers and firms in response to fiscal variables.

We build on the existing literature by considering the relationship between metropolitan area characteristics and wage distributions (rather than average wages) across areas. If workers at different points in the income distribution value certain amenities or fiscal characteristics differently, workers at some points in the distribution might require a wage premium to live in a metropolitan area while others 
may not. For example, if Houston has a tax structure that is nominally more progressive than other cities, workers at the high end of the income distribution would, ceteris paribus, require relatively more pre-tax compensation to live in Houston than would those at the low end of the income distribution. As a result, wage differentials would be higher in Houston than other metropolitan areas, and we would not expect this difference to be reduced through migration of households and firms.

Understanding how wage distributions respond to fiscal policy can shape how policy makers think about both inequality in overall well-being and wage inequality. For example, differences in wage inequality across areas may not reflect differences in well-being if groups are accepting lower wages to live in areas with fiscal packages that are attractive to them. Similarly, measured national wage inequality may overstate or understate well-being inequality depending on how groups sort across metropolitan areas. $^{2}$ The existence of a relationship between wage inequality and local fiscal policy due to migration of workers could also suggest that redistribution at the national level may be more effective than at the state or local level.

In the analysis that follows, we use a simple theoretical model to show one potentially important mechanism by which local fiscal policy could affect relative wages. Although we cannot test specific predictions of the model, we examine the model's broad implications using Census data, and demonstrate that fiscal characteristics are indeed correlated with the wage premia earned across different points in the income distribution. The analysis suggests one explanation for why differences in wage structures across metropolitan areas persist, even after accounting for the observable characteristics of workers.

We follow the literature on the sources of long-run differences in average wages across cities (see, for example, Roback (1982), Gyourko and Tracy (1989, 1991), Beeson (1991)) to construct a model of equilibrium wage inequality. We then use data on 131 metropolitan areas from the 1980, 1990, and 2000 Censuses of Population and the 1977, 1987, and 1997 Censuses of Governments to investigate the relationship between urban wage structure and local fiscal policy. Because our interest is in wage

\footnotetext{
${ }^{2}$ Related points are made in work by Moretti (2008) and Albouy (2009).
} 
adjustments across metropolitan areas, our regression analyses focus on a smaller subset of labor markets with relatively little variation within metropolitan areas in the provision of public goods. Specifically, our primary sample includes the 44 metropolitan areas with the lowest degree of school district choice. We also discuss results based on the full sample.

Our results indicate that local fiscal policies are related to wage distributions. Fiscal variables are significant predictors of wage inequality. Given the fact that local fiscal policies are endogenously determined by residents of areas, we cannot claim that our findings represent the causal impact of local fiscal policies on wage structure. ${ }^{3}$ Nevertheless, our findings are consistent with a model in which wages for different types of workers adjust so that the marginal worker of each type is indifferent among metropolitan areas. In other words, pre-tax wage distributions reflect compensating differentials associated with living in a metropolitan area with a given fiscal bundle. Based on the promise of the results presented here, we believe future work should exploit exogenous sources of variation in fiscal policy to identify the causal impact of taxes and expenditures on the wage distribution

\section{Theoretical Framework}

In this section we present a simple model which shows how local fiscal conditions can affect the wage distribution when both workers and firms are mobile across regions. We extend Beeson's (1991) model of the effect of non-produced amenities on wage structure to include fiscal characteristics of the local government, and extend Gyourko and Tracy’s $(1989,1991)$ examination of the relationship between local fiscal policies and average wages to look at the effect of local fiscal policies on the distribution of wages. The model demonstrates that different tax structures and different mixes of goods provided by local governments can result in different distributions of gross wages because the values of taxes and local public goods to different types of households can be capitalized into wages or land prices. It is important to recognize that this is not a model of economic incidence of taxes-the model we present here

\footnotetext{
${ }^{3}$ For example, Alesina, Glaeser, and Sacerdote (2001) argue that population heterogeneity affects the willingness of the electorate to vote for transfers.
} 
is concerned with pre-tax wages. Net of tax wages are assumed to be unaffected by tax policy. ${ }^{4}$ Tax rates are constant for a given individual, so in the discussion below marginal and average tax rates are equivalent.

Cities are assumed to differ in two respects: the natural amenities with which they are endowed and the locally provided package of taxes and public services. Both are assumed to be taken as given by all potential residents and to be available uniformly throughout the urban area. Individuals are completely mobile across locations, but work in the city where they live, and supply one unit of labor. Similarly, physical capital is completely mobile and employed along with labor, land, and intermediate goods to produce a composite traded good, $X$, that is available everywhere at a constant price and serves as the numeraire.

There are two types of individuals, low-skill (low-wage) and high-skill (high-wage). Individual utility depends on consumption of the composite good $X$, land $h$, as well as the amenities $A$, and services $G$ offered in their community,

$$
U^{i}=U_{i}\left\{X_{i}, h_{i} ; A, G\right\}
$$

where $i$ indexes worker type ( $i=1,2 ; 1$ indicating low-skill workers). The gross-of-tax price of the composite good is $1+s$, where $s$ is the sales tax rate and the pre-tax price of the composite good is normalized to equal one. ${ }^{5}$ The gross-of-tax rental price of land $r^{*}$ is the same for all residents and firms in the city and is given by $(1+t) r$ where $t$ is the local property tax rate and $r$ is the pre-tax land rental rate. Individuals maximize their utility subject to the following budget constraint:

$$
(1+s) X_{i}+(1+t) r h_{i} \leq\left(1-z_{i}\right) w_{i}
$$

where $w_{i}$ is the gross wage income and $z_{i}$ is the personal income tax rate for type $i$.

\footnotetext{
${ }^{4}$ Feldstein and Wrobel (1998) find evidence that net wages are unaffected by nominal progressivity in state tax rates.

${ }^{5}$ In the theoretical model, we consider the non-land component of housing to be part of the composite good, and thus the sales tax is defined to include both the usual sales tax and the tax on housing. The property tax is the tax on land. In the empirical work, the property tax includes taxation on both land and housing structures.
} 
In equilibrium, utility of all workers of the same type must be the same at all locations. If this were not the case, workers could move and increase utility. Written in the form of an indirect utility function, equilibrium for worker type $i$ requires

$$
\bar{V}^{i}=V\left\{w_{i}^{*}, r^{*},(1+s) ; A, G\right\}
$$

where $\bar{V}^{i}$ is the nationally given utility level for type $i$ workers and $w_{i}{ }^{*}\left(=\left(1-z_{i}\right) w_{i}\right)$ is the net wage.

In each city firms produce the composite commodity $X$, using $N_{i}$ workers of type $i$, land $\left(L^{P}\right)$, and intermediate goods according to a constant returns to scale production process. These inputs are imperfect substitutes in production. Local amenities and public goods can have a Hicks' neutral effect on the productivity of firms, and firms can vary the amount of amenities and public goods in production only by varying their location. Because firms sell their product in a national market at a common price, equilibrium for firms requires that unit costs $C$ are the same in all locations and equal to the price of $X$, assumed to be 1. For firms in a given location this implies

$$
C\left\{w_{1}, w_{2}, r^{*},(1+s) ; A, G\right\}=1
$$

where $s$ is the sales tax on intermediate goods, which is assumed to be the same rate as that applied to consumer goods.

Given the national level of utility for each type of worker, $\bar{V}^{i}$, and the price of the composite commodity (=1), the equilibrium conditions for the two types of households (3) and the equilibrium condition for firms (4) jointly determine the wage and rent differentials across cities. Taking the total derivatives of (3) and (4) and solving for $d \log r$ and $d \log w_{i}$ using Roy's identity and Shepard's lemma yields the expressions for the total differentials of wages and land rents across cities. These are equations (5) and (6) shown in the appendix.

The analysis suggests that increases in the value of public goods or amenities to either households or firms increase rents per unit of land by an amount equal to the value of the public service or amenity 
per unit of land. Thus the positive value of amenities and of public goods is fully capitalized into land values. Differences between workers and firms in their valuation of local amenities, public goods, and taxes will be reflected in average wages (see Gyourko and Tracy, 1989). Here we show that differences between different types of workers in their valuation of amenities, public goods, and taxes will be reflected in relative wages.

We use this model to examine the effects of changes in the tax structure on wage dispersion by considering the effect of tax changes on the difference between $d \log w_{2}$ and $d \log w_{1}$. The effect will have two parts: a direct effect of the change, and a change resulting from capitalization of the tax into land values. This second part is due to the fact that $d \log r$ enters the wage derivative equation (equation (5) shown in the appendix). As long as the shares of income spent on land ( $k_{1}$ and $\left.k_{2}\right)$ are not the same, the effect of a change in tax structure on pre-tax wages will partially depend on what happens to land prices. If the shares differ, then the wages of the group spending less of its income on land would increase. Intuitively, as taxes are capitalized into land values, then the group spending a lower share of its income on land is not receiving the same amount of compensation for the higher taxes. Consequently, wages would have to adjust to compensate, or the less compensated group would find it beneficial to migrate. Pre-tax wage differentials would thus increase as a result of a change in tax structure if, for example, low-wage workers spend a larger fraction of their income on land.

For simplicity in analyzing the effects of tax changes in this model, however, we abstract from the capitalization effect and assume $k_{1}=k_{2}=k$ - the two groups spend the same proportion of their income on land. In this case, the term in (5) containing $d \log r$ will drop out (see appendix). Using this assumption, we consider the impacts on wage differentials of four changes: implementation of a nominally progressive income tax, a change in property taxes, a change in the sales tax, and a change in public services. These comparative statics are for illustrative purposes only; due to data limitations we are 
not able to test these specific predictions of the model. Nevertheless, the exercise offers a useful illustration of how fiscal variables might affect the wage structure in a local area.

Consider first the case of an income tax where the tax rate on the high-wage workers is raised above the tax rate on the low-wage workers. ${ }^{6}$ From equation (5) in the appendix, the effect is to increase pre-tax wage differences:

$$
\frac{d \log w_{2}-d \log w_{1}}{d z_{2}}=\frac{1}{1-z_{2}}>0
$$

In equilibrium, wages of high-skill workers must rise to compensate them for the increased tax burden, which increases the spread between the wages of the two types of workers. ${ }^{7}$ The effect of an increase in the property tax depends on whether the income tax is nominally progressive $\left(z_{2}>z_{1}\right)$, regressive $\left(z_{2}<z_{1}\right)$, or proportional $\left(\mathrm{z}_{2}=\mathrm{z}_{1}\right)$ :

$$
\frac{d \log w_{2}-d \log w_{1}}{d t}=\left[\frac{1}{1-z_{2}}-\frac{1}{1-z_{1}}\right] k .
$$

If the income tax is proportional, then changes in the property tax have no effect on wage differentials. In the case of a progressive income tax, however, an increase in the property tax will again increase pre-tax wage inequality. This is because we have assumed that the two groups spend the same fraction of their income on land, so compensation for higher property taxes on the high-wage workers must come through the labor market. ${ }^{8}$

\footnotetext{
${ }^{6}$ We consider any income taxes that differ across metropolitan areas; these include both state and local income taxes. A majority of state taxes do include graduated tax rates by income. States vary in their degree of progressivity. In California, for example, the top ten percent paid 73 percent of income taxes in 2003 (Rosenberg, 2007).

${ }^{7}$ This is the same effect found by Feldstein and Wrobel (1998). Their model is similar to the one presented here, with a primary exception being that they consider only one form of taxation.

${ }^{8}$ As a simple example, consider a low-wage worker earning 25,000 and a high wage worker earning 50,000. Both workers spend 25 percent of pre-tax earnings on land, which is taxed a rate of 2 percent. In the case of a 5 percent proportional income tax, the after tax incomes will be 23,625 and 47,250, respectively, so that the high income worker will still earn twice as much as the low income worker. If instead the income tax rate is 3 percent on the low income worker and 7 percent on the high income worker, the after tax incomes will be 24,125 and 46,250 with a ratio of 1.92. This ratio is not sustainable in equilibrium and relative wages will adjust accordingly.
} 
The third change we consider is an increase in sales taxes. The effect of this change depends on the fraction of after-tax income that each group spends on consumption:

$$
\frac{d \log w_{2}-d \log w_{1}}{d s}=\frac{1}{1-z_{2}}\left(\frac{x_{2}}{w_{2}}\right)-\frac{1}{1-z_{1}}\left(\frac{x_{1}}{w_{1}}\right) .
$$

Inequality will increase if the high-wage individuals consume a larger portion of their after-tax income, and will fall if the low-wage individuals consume the larger fraction. The intuition for this result is straightforward: the group consuming a larger share of its income pays a relatively larger share of the sales tax; consequently that group must be compensated through the labor market.

Finally, we consider an increase in public spending (note that since amenities and public spending enter the model in the same way, these results will hold for a change in amenities as well.) In this case, the effect on inequality depends on the monetized values of the marginal utility of the public service for the two groups $\left(p_{G} / w\right)$ :

$$
\frac{d \log w_{2}-d \log w_{1}}{d G}=\frac{1}{1-z_{2}}\left(\frac{p_{G_{2}}}{w_{2}}\right)+\frac{1}{1-z_{1}}\left(\frac{p_{G_{1}}}{w_{1}}\right)
$$

If the high-wage group values the public service more relative to their after-tax wages, pre-tax wage inequality will decrease. This is because the group valuing the service more will accept lower wages to live in this city.

This model makes several strong assumptions, including that land prices are uniform throughout the local market and that taxes and public goods are the same at all locations in the local market. To the extent that metropolitan areas are made up of many local communities with fixed geographic boundaries, each offering distinct fiscal packages, and to the extent that households sort themselves across these communities based on their preferences for these fiscal packages, the value of these fiscal packages can be capitalized into land prices. However, if households do not sort completely to form homogeneous communities, relative wages can be affected as described by this model. 
Our empirical work gives special attention to metropolitan areas that have relatively little scope for within-area sorting, as these are the areas where the model is most likely to be applicable. As discussed below, these "low-choice” areas are not representative of all U.S. metropolitan areas, but offer a useful example of what might happen when workers sort across metropolitan areas in response to fiscal variables.

It is important to note that our empirical work does not offer a direct test of the model. Perhaps most importantly, the model suggests that workers are sensitive to tax rates, which we do not observe. Instead, we use tax revenues per capita. Furthermore, the property tax in the model is a tax on land alone, while in our data it is a tax on structures and land. We are also unable to observe fiscal environments or wages within metropolitan areas. Nevertheless, in the low-choice sample, we do expect to find a relationship between the fiscal variables and wage inequality.

\section{Data Construction}

The data used in this paper come from two main sources. The measures of wage dispersion and demographic characteristics are calculated from data reported in the Census 5\% Public Use Micro Samples (PUMS), 1980, 1990 and 2000. The PUMS data are attractive for our purposes for a number of reasons. First, they report geographic detail which allows us to examine wage distributions in 131 geographically distinct labor markets. Second, each individual in the PUMS is asked questions related to earnings, industry of employment, and demographic characteristics. This information allows us to determine measures of the variability of wages in a metropolitan area (such as the difference between the 90th and the 10th percentiles). Finally, the samples are very large, which improves the precision of our estimates of city wage structures.

We restrict our sample to male wage and salary workers aged 16 to 65, who reported usual hours worked per week of 35 hours or more, worked at least 49 weeks during the reference year, and were not self employed. The hourly wage is calculated as annual wage and salary income, divided by the product of usual hours worked and weeks worked last year. We limit the sample to men with positive hourly 
wages. The geographic information reported in the PUMS is used to link individuals to geographic areas. Unfortunately, the Census does not report consistent sub-state geography in the decennial Censuses. We use the template developed by Jaeger, Loeb, Turner, and Bound (1998) to construct 131 geographic areas with consistent boundaries in 1980 and 1990, and use a similar methodology to incorporate the 2000 data. $^{9}$ The areas generally coincide with the census-defined Consolidated Metropolitan Statistical Areas (CMSAs). ${ }^{10}$ The 1980 sample includes over 1.32 million men, the 1990 sample includes almost 1.43 million men, and the 2000 sample includes almost 1.61 million men. The number of men per CMSA ranges from 1,060 (Brownsville, TX in 1980) to 148088 (New York, NY in 2000). The average CMSAyear cell exceeds 10,000 men.

We also compute wage premia, or skill-adjusted wages, for each man in the sample. We run a national wage regression for each year which includes the log(wage) on the left hand side. Control variables include a quartic in potential experience, dummies for race/ethnicity categories (non-Hispanic white omitted, non-Hispanic black, Hispanic, and other), an indicator for immigrant status, and dummies for education categories (no high school, some high school, high school exactly omitted, some college, college graduate, and post-graduate). For each individual we calculate the residual from this regression we call this the wage premium or wage residual. The premium for each individual reflects earnings that are above or below the level that would be predicted based on observable characteristics.

We aggregate individuals to the CMSA-year level. Our primary analysis focuses on metropolitan areas with relative homogeneity in local fiscal policy because the theoretical model more closely aligns with the environment in these areas. Specifically, we select the metropolitan areas in the lowest third of a school district choice index (Rothstein, 2007); in these areas, students are concentrated in a small number of school districts. ${ }^{11}$ This "low-choice” sample consists of 44 metropolitan areas.

\footnotetext{
${ }^{9}$ See appendix for details.

${ }^{10}$ We use CMSAs because they allow us to use comparable geographic areas across years.

${ }^{11}$ We use Rothstein's school choice index, which is one minus a Herfindahl index of $8^{\text {th }}$ grade school district assignment for a metropolitan area.
} 
Since educational expenditures are a large share of state and local budgets and a major source of within-metro-area variation in fiscal policy, we argue that individuals in an area with little school district choice face more homogenous fiscal environments than individuals living in other metropolitan areas. Education expenditure represents the largest expenditure category and about a third of total expenditures in our sample, and schools within a district are presumably more homogenous in terms of quality than schools across districts. Education provision is mainly financed through state income tax and local property tax; these taxes are likely to be constant within a district but differ across districts. Furthermore, the administrative pattern of school districts often reflects a more general organization of government activity. Places with town-based school districts may also have town-based trash collection, fire protection, etc. Though there is almost always some scope for Tiebout sorting within metropolitan areas, the ability to sort is constrained in areas with few school districts or one dominant school district.

Low-choice areas tend to have different characteristics than other areas, as is evident from Table 2. ${ }^{12}$ On average they have more wage inequality, lower taxes and expenditures, and lower levels of education than the full sample. They are mainly in the South. Because these areas tend to be growing rapidly over the sample period, they may adjust more quickly to changes in fiscal conditions than other areas. Therefore, it is important to keep in mind that our results for this sample may not generalize to other metropolitan areas. We believe this disadvantage is outweighed by the increased confidence we gain when the characteristics of our sample more closely align with the theoretical model.

Using the data aggregated to the CMSA-year level, we construct three measures of intra-city wage dispersion and wage structure. The first is an estimate of the 90-10 wage gap. We calculate the $10^{\text {th }}$ percentile in the $\log$ (wage) distribution for a given CMSA-year cell and subtract it from the $90^{\text {th }}$ percentile in the $\log$ (wage) distribution. The 90-10 wage gap gives an indication of the overall dispersion of wages in the local economy at a point in time. ${ }^{13}$

\footnotetext{
${ }^{12}$ A full list of the 44 low-choice areas is available in the appendix.

${ }^{13}$ We focus on the 90-10 ratio rather than the variance of wages because of measurement error in the tails of the distribution. Measurement error stems from the fact that the earnings of up to $2 \%$ of men are top-coded in each
} 
We also use the wage premiums (residuals) from the national wage regression (described above) to construct two additional measures of dispersion. One is the median premium earned by men in the $9^{\text {th }}$ decile in a CMSA-year cell relative to the median premium earned by men in the $2^{\text {nd }}$ decile-we call this the "decile premium gap." The other is the median premium earned by college graduates (that is, earnings above that which would be predicted based on observable characteristics) in the CMSA-year cell relative to the premium earned by high school graduates, which we call the "education premium gap." The theoretical model suggests that premiums should be lower for a group which has a high relative valuation of a given fiscal policy. Thus, in the context of the model, dispersion in skill-adjusted wages indicates that a low-SES group (where SES is measured by income rank or educational level) has a higher valuation of the policy (as measured by willingness to accept a lower wage) than a high-SES group.

Measures of local revenues and government expenditures are computed using data from the finance files of the U.S. Census Bureau's Census of Governments (COG) for 1977, 1987 and 1997. These files provide detailed budgetary information for all levels of government in the United States. Since multiple governmental units (including states, counties, cities, towns, school districts and special districts) tax individuals and firms within a given metropolitan area, our measures of revenue and government spending take into account all levels of government below the federal level. For each CMSA, we aggregate revenues and expenditures from all component counties, cities, towns, school districts, and special districts. ${ }^{14}$ We also add state revenues and expenditures in proportion to the fraction of the state population living in the CMSA.

Revenues are divided into the following categories: property taxes, sales taxes, personal income taxes, social insurance taxes (including unemployment insurance and workers compensation insurance), fees and charges (includes utility revenue, transport revenue, and other fees and charges), and all other

year. Top-codes changed over time, making comparisons across years difficult. In addition, usual hours worked may differ substantially from an average measures of hours worked per week last year.

${ }^{14}$ For cities, towns, school district and special districts that cross county lines, the COG indicates a primary county. We treat the unit as belonging to the CMSA associated with its primary county. 
revenues. ${ }^{15}$ Expenditures include infrastructure expenditures, education expenditures, public safety expenditures, health expenditures, welfare expenditures (includes cash assistance, workers compensation, etc.), and other expenditures. Note that expenditures and taxes need not be equal due to intergovernmental transfers - in actuality, expenditures substantially exceed revenues.

CMSA population size, population density, and region dummies are included as controls. We also control for business cycle and price effects using metropolitan area-level unemployment rates and the shares of CMSA-level employment in nine industry categories. In addition, we control for city-level demographic composition (race, ethnicity, immigration status and educational distribution) and measures of amenities including heating and cooling degree days, violent and property crime, number of museums, and the per capita number of restaurants. Our preferred specification pools data from all three Census years, and we include year dummies in all pooled regressions.

Table 1 gives summary statistics for wage distributions in the 131 metropolitan areas. The unit of observation is the CMSA-year cell and the analysis is unweighted. As has been widely noted elsewhere, wage dispersion increased between 1980 and 2000. The $90^{\text {th }}$ percentile of wages rose over time, while real wages fell at the $50^{\text {th }}$ and $10^{\text {th }}$ percentile of an average metropolitan area. The 90-10 gap rose from 1.29 to 1.44 in an average CMSA. We also examine wage premiums in different parts of the CMSA income distribution. By construction, the average man in the sample in each year has a wage premium (residual after controlling for observable characteristics) of zero. However, because wages reflect both observed and unobserved skills, and because returns to unobserved skills increased, relative wage premiums fell at the bottom of the distribution. The median premium of second decile men in a typical

\footnotetext{
15 Although fees and charges are not taxes, they are a cost faced by residents of an area and they do allow for higher levels of expenditure under a balanced government budget. An area with garbage collection fees may be less desirable than an otherwise identical area without such fees. Unfortunately, the data do not allow us to distinguish between charges that can be thought of as optional fee-for-service payments and those that are more akin to a head tax. In the appendix, we present results without fees and charges included. Also, although unemployment insurance exists in every state, each state administers a separate unemployment insurance program within guidelines established by Federal law. States differ in the standard rate charged to employers, the definition of the rate base, and the way experience rating is done.
} 
CMSA-year cell went from -0.35 in 1980 to -0.43 in 2000, whereas the median premium for a $9^{\text {th }}$ decile man barely changed. The decile premium (the difference in wage residuals for high- and low-earners) rose to 0.72 by the year 2000 in the typical metropolitan area. Returns to education also increased over the period. Wages of high school graduates fell substantially in the average metropolitan area, while wages of college graduates fell slightly. The typical return to a college education rose from 0.34 in 1980 to 0.46 in $2000 .^{16}$

There is considerable heterogeneity in the degree of wage inequality across the sample. The 9010 ratio ranges from 1.02 to 1.79 and the estimated return to college education ranges from 0.13 to 0.63 . Dispersion after accounting for observable characteristics also varies across areas. The decile premium gap (the difference in the $9^{\text {th }}$ decile premium and the $2^{\text {nd }}$ decile premium) ranges from 0.46 to 0.93 and the education premium gap (the difference in the college premium and the high school premium) ranges from -0.26 to 0.19 .

Table 2 gives information about the other variables used in the analysis. Per capita tax burdens rose over time in real terms from almost 2900 dollars to almost 3900 dollars in the full sample and from 2500 dollars to 3500 dollars in the low-choice sample. ${ }^{17}$ The share of taxes coming from income taxes and user fees rose over time, while reliance on the property tax fell. Expenditures also rose substantially_from about 3700 dollars per capita to almost 5200 dollars per capita in the full sample and from 3200 dollars to 4800 dollars per capita in the low-choice sample. Increases were recorded in every category of spending.

The control variables follow expected patterns. Industrial composition was marked by a rise in services and a decline in manufacturing. The fraction immigrant, fraction black, and fraction Hispanic increased over the 1980 to 2000 period. Education levels increased and crime fell in the typical CMSA.

\footnotetext{
${ }^{16}$ Returns to college education are calculated by taking each CMSA-year sample, keeping those with exactly high school or exactly college, and running a log(wage) regression with controls for race/ethnicity, immigrant status, and a quartic in potential experience. The "return to education" is the coefficient on the college dummy in the regression.

${ }^{17}$ All dollar amounts are in real (2000) dollars, calculated using the CPI-U base year 1982-4.
} 


\section{Wage Distributions Across Cities and Their Persistence}

As noted above, there are substantial differences in wage inequality across metropolitan areas. Figure 2a shows the $90-10$ wage gap ( $90^{\text {th }}$ percentile of log wage minus $10^{\text {th }}$ percentile of log wage) for the 131 areas in our data for 1980 and 2000. In 2000, the most unequal metropolitan area in the sample is San Diego with a 90-10 difference in log wages of 1.79, and the most equal is Appleton with a 90-10 difference of 1.13. A similar range of values is evident across the low-choice sample in Figure $2 \mathrm{~b}$. Figures 3 and 4 show dispersion in the two other measures of inequality - the decile premium gap (premium of the $9^{\text {th }}$ decile minus premium of the $2^{\text {nd }}$ decile) and the education premium gap (premium of college educated minus premium of high school educated). Because the premium gaps compare residuals for different groups of workers, Figures 3 and 4 indicate that the variation in wage dispersion across metropolitan areas cannot be solely attributed to differences in observable characteristics of workers. This variation is particularly evident in the full sample.

It is also evident from Figures 2, 3, and 4 that wage inequality tends to persist over time. The most unequal cities in 1980 tend to also be highly unequal in 2000. The correlation in the 90-10 gap in 1980 and in 2000 is 0.73 for the full sample and 0.63 for the low-choice sample. Some of these long-run differences are due to observable characteristics, but there is also persistence in wage residuals. The decile premium gap and the education premium gap are also sticky, though to a lesser degree. The correlations between 1980 and 2000 are 0.39 and 0.44 in the full sample and 0.32 and 0.15 in the lowchoice sample.

Given evidence that wage distributions differ across metropolitan areas, that these differences are not entirely due to differences in observable characteristics, and that these differences persist over time, we turn to understanding the determinants of wage dispersion. The theoretical model suggests that metropolitan amenities and fiscal policies might play a role. The following section examines the relationship between fiscal policy and wage distributions in a regression setting. 


\section{Regression Analysis}

The model presented in section II suggests that differences in wage dispersion can reflect regional differences in local fiscal policies that affect the utility of households and hence the supply of different types of workers. For example, the model predicts that pre-tax wage inequality will be higher ceteris paribus if (1) income taxes are higher for high-income individuals, (2) property taxes on land are higher (as long as income taxes are progressive), (3) sales taxes are lower (if the less-skilled consume a higher fraction of income), and (4) expenditures are higher in categories that are valued more highly by lessskilled individuals.

As discussed above, our data do not allow us to directly test the predictions of the model. In this section, we pursue the more modest goal of examining whether there is evidence of a relationship between wage dispersion and local fiscal policies in the data. We begin by examining the relationship between overall wage dispersion and local fiscal policies. In the next section we examine how fiscal policies are related to wages at different points in the wage distribution.

We examine the relationship between the distribution of skill-adjusted wages and local fiscal policies using the following model:

$$
Y_{j}=a+\beta_{T} T_{j}+\beta_{G} G_{j}+\beta_{D} D_{j}+\beta_{A} A_{j}+\beta_{R} R_{j}+u_{j}
$$

in which $Y_{j}$ is a measure of the dispersion of skill-adjusted wages in MSA $j$, and $T_{j}, G_{j}, D_{j}, A_{j}$, and $R_{j}$, are vectors reflecting local taxes, public expenditures, local labor demand, amenities, and region, respectively. As above, we use three summary measures of dispersion: (1) the 90-10 wage gap, (2) the decile premium gap, and (3) the education premium gap. ${ }^{18}$

To capture variation in tax policy we use the log of total taxes per capita and the log of revenues from property taxes, sales taxes, user charges and fees, contributions to social insurance programs, and other taxes. The revenue from income taxes is the omitted category in our regressions. ${ }^{19}$ To capture

\footnotetext{
18 These terms are defined in the previous section.

${ }^{19}$ We choose income tax as the omitted variable because it takes zero values in some areas and therefore cannot be
} 
variation in the types of goods and services provided by local governments we include the log of per capita government expenditures on infrastructure, public safety, education, health, safety net programs, and other categories. We capture demand factors with the log of the population size, the region, and the share of employment in each of nine broadly defined industries. We control for relative supply with variables measuring education shares, race/ethnicity composition, and immigrant fractions in the metropolitan area and year. We also control for amenities including heating and cooling degree days, violent and property crime, number of museums, and per capita number of restaurants.

We estimate this model using pooled data from the 1980-2000 censuses using the preferred "lowchoice” sample. Each observation is a metropolitan area-year. The three columns in Table 3 each represent a model with a different measure of dispersion as the dependent variable - the 90-10 difference in log wages, the excess premium earned by the $9^{\text {th }}$ decile relative to the $2^{\text {nd }}$ decile, and the excess premium earned by college graduates relative to high school graduates. We test the joint significance of the fiscal variables. They are jointly significant at the 11, 1 and 6 percent levels in columns I, II, and III respectively. In other words, fiscal policies are related to wage dispersion in the data. The relative predictive power of the revenue variables and the expenditure variables differs across models.

As is evident in Table 3, most individual measures of fiscal policy are statistically insignificant. Exceptions include the coefficient on total taxes which is consistently negative and is marginally significant in one specification. Similarly, the coefficient on the property tax is consistently positive across all three specifications and statistically significant in one. The positive coefficient implies that there is more inequality when overall taxes are low and the property taxes are important sources of government revenue. The coefficients on fees and charges are also consistently positive (though statistically insignificant). There are many reasons that these fiscal variables are related to inequality, and we cannot claim the relationship is causal. However, the pattern is consistent with the idea that high-

included in the model in log form. A limitation of the analysis is that we use tax revenue by category rather than tax rates; identifying tax rates at all levels of government for all metropolitan areas is beyond the scope of this paper. Changes in revenue could be due to exogenous changes in income or property values. We do our best to account for this in the regression analysis. 
income workers receive a compensating differential to live in an area with a high share of revenue collected from property taxation and fees. Note that the sample here is restricted to "low-choice" areas; the pattern for property taxes is less consistent in metropolitan areas where workers can easily Tiebout sort. Results for the full sample are shown in Appendix Table 3 and discussed in the appendix.

Though the expenditure variables are individually insignificant, some do display consistent signs across regression models. Coefficients on social insurance and infrastructure expenditures are positive, suggesting wages for the less-skilled are relatively low in areas with high social insurance and infrastructure spending. This could reflect a willingness of low-income workers to accept lower wages in compensation for access to public services, or could be the result of unobserved skill heterogeneity across metropolitan areas.

Although not shown in the table, some of the other control variables are associated with inequality. The indicators for 1990 and 2000 (with 1980 as the reference year) have positive and significant coefficients, as would be expected given the large literature suggesting inequality increased in the final decades of the twentieth century. Wages are more dispersed in areas with more moderate weather and with more museums. Inequality is also related to the industrial mix and educational distribution in the area. Again, these relationships are associations and may not reflect a causal influence of metropolitan characteristics on the wage structure.

To summarize, we find evidence that the dispersion of skill-adjusted wages within a city is related to fiscal structure. Though there are many possible explanations for a relationship between fiscal conditions and wage dispersion, our theoretical model points to one potentially important mechanism. The fiscal policy variables are jointly significant and alone account for 18 to 45 percent of the variation in the wage premium differences across low-choice metropolitan areas and across all areas (results not shown). Though we cannot be sure the relationship is causal, the empirical patterns suggest that fiscal policy may be one determinant of long-run differences in wage dispersion across metropolitan areas. 


\section{Effects of Fiscal Policy across the Income Distribution}

The summary measures of wage dispersion used in the analysis presented in Table 3 may mask a more complicated relationship between fiscal structure and wage premia. We examine whether this is the case by exploring how fiscal variables affect wage premia in each percentile of the income distribution. To do so, we divide our sample into 100 subsamples, each representing a given percentile of the wage distribution in each metropolitan area. We then run 100 wage regressions of the following form, one for each percentile group, which include the standard individual labor market characteristics and all the citylevel variables included in Table 2:

$$
\ln w_{a g e} e_{i j}=\alpha+\beta_{h c} H C_{i}+\beta_{T} T_{j}+\beta_{G} G_{j}+\beta_{A} A_{j}+\beta_{D} D_{j}+\beta_{R} R_{j}+u_{i j}
$$

where $H C_{i}$ is a vector of characteristics of individual $i$ measuring potential experience (as a quartic), race/ethnicity (four categories), and education (six categories) and immigrant status; the other vectors of characteristics of CMSA $j$ are as defined above. Note that this approach differs slightly from the approach used in Table 3 because the effects of all variables are allowed to vary by income percentile. We also control for the median wage in these regressions as a normalization; the effects should be interpreted as effects on wages relative to the median wage. The presented results focus on the 44 areas in the low-choice sample. Though the regressions are run using individual-level data, they are weighted so that each of the low-choice metropolitan areas have equivalent importance in each regression. ${ }^{20}$

Results from these regressions are shown in graphical form, with each dot representing the coefficient on a given fiscal characteristic from one regression. Controlling for the median wage ensures that the $50^{\text {th }}$ percentile has a coefficient of approximately zero - in other words, all coefficients are interpreted as the effect relative to the effect on the median worker. Because the top and bottom three percentile groups tend to be outliers, they are not shown in the pictures. Standard errors from any given coefficient are typically large and are not shown on the graphs.

\footnotetext{
${ }^{20}$ The advantage of weighting in this way is that no one large metropolitan area can unduly influence the results.
} 
Figure 5 shows the coefficients on the log of per capita taxes, conditional on the distribution of tax instruments and expenditures. If one takes the model seriously, the high wage premia at the bottom of the distribution suggest that low-income workers require more of an incentive than middle-income workers to work in a high-tax city.

Figures 6 through 10 show coefficients on shares of the tax burden from different sources, with income tax serving as the omitted category, and with total taxes and expenditure categories held constant. An upward slope to the dots suggests that workers at the bottom of the distribution prefer a given tax to an income tax, relative to high-earning workers. This is the case with the property tax and "other taxes", for example. It appears that workers above the median are particularly averse to the property tax, a prediction consistent with the model in some circumstances. The opposite pattern is true for sales and social insurance taxes; a heavy reliance on revenues from these taxes is associated with higher wages at the bottom end of the distribution. Since sales and payroll taxes tend to be regressive, the results are consistent with the notion that low-income individuals require compensation to live in an area with a regressive tax structure.

Figures 11 through 16 examine the effects of per capita expenditures on various categories, conditional on the tax burden and sources of tax revenue. Again, in the context of the model, an upward slope suggests that the bottom of the wage distribution values the expenditure more than the top, and as a result is willing to accept a lower nominal wage. This appears to be true for social insurance expenditures. Coefficients on education and public safety expenditures follow a downward-sloping pattern; in the context of the model this implies that such expenditures are relatively valuable to middleand upper-income residents. Several categories of expenditure exhibit an inverted "U" shape, implying the middle-income group values such expenditures less than other groups; these include infrastructure, health, and other expenditures. The low wages at the bottom of the income distribution associated with infrastructure expenditures may reflect the high valuation the poor place on public transit (Glaeser, Kahn, and Rappaport, 2008), for example. 
These graphs offer a starting point for thinking about how fiscal policies may affect nominal wage inequality. We cannot rule out the importance of unobserved factors shaping both fiscal policy and the wage distribution. For example, agglomeration economies could make high-skilled workers more productive and increase inequality, but could also be related to local fiscal conditions. ${ }^{21}$ Furthermore, the redistributive tendencies of local fiscal policies could be related to the distribution of population characteristics. While we do not discount the importance of these factors, our work suggests that exploring the nature of the link between fiscal policy and wages is a potentially fruitful avenue for future research.

\section{Summary and Conclusions}

This paper contributes to the literature on urban wage structures by exploring differences in the degree of wage dispersion that exists within urban areas. We hypothesize that local fiscal policy may contribute to differences in wage distributions, particularly wage dispersion not explained by observable skill. We present a theoretical model which illustrates one potentially important mechanism by which local fiscal policy can affect the structure of wages. We then evaluate whether such a relationship between local fiscal policy and wage structure exists. Our analysis uses data on 131 metropolitan areas from the 1980, 1990, and 2000 Censuses of Population, and the 1977, 1987, and 1997 Census of Governments.

Overall, we find that the structure of wages in an urban area is related to the structure of taxes and the composition of local expenditures. In particular, wage premia (wages unaccounted for by observable individual characteristics) in some parts of the distribution are higher than those in other parts of the distribution, and these differences are correlated with tax and expenditure policy. Without accounting for any other city-level factors, roughly a quarter of the variation in wage dispersion is explained by local

\footnotetext{
${ }^{21}$ Though we cannot rule out agglomeration effects, it is important to note that our percentile regressions control for population size and the educational distribution of the population. The effects of these variables implicitly vary by income percentile, so we have gone some distance towards accounting for these effects in our regressions. See Glaeser and Gottlieb (2009) for a discussion of agglomeration economies in the context of a spatial equilibrium model.
} 
fiscal policy variables. Our theoretical model suggests a mechanism by which one would expect such a relationship.

Our model implies that differing compensating wage differentials across the wage distribution for fiscal characteristics can affect urban wage inequality. It is possible that the direction of causality might be the reverse: differences in wage structure lead to different fiscal structures. Future research should attempt to isolate the causal impact of taxes and expenditures on urban wage inequality by exploiting exogenous policy shocks. Enriching the model to account for Tiebout sorting within metropolitan areas is another priority for future research.

Though we view the analysis presented here as a first step, understanding how wage distributions respond to fiscal policy is quite important. Policy-makers are presumably concerned with inequality of well-being rather than inequality of nominal wages; our analysis highlights the difference between these concepts. Furthermore, the degree to which worker mobility equalizes utility across areas may affect the optimal geographic level of redistribution. 


\section{Appendix}

\section{A. Details of the Theoretical Model}

Given the national level of utility for each type of worker, $\bar{V}^{i}$, and the price of the composite commodity (=1), the equilibrium conditions for the two types of households (3) and the equilibrium condition for firms (4) jointly determine the wage and rent differentials across cities. Taking the total derivatives of (3) and (4) and solving for $d \log r$ and $d \log w_{i}$ using Roy's identity and Shepard's lemma yields the following expressions for the total differentials of wages and land rents across cities:

$$
d \log w_{i}=\frac{1}{1-z_{i}}\left[d z_{i}+k_{i} d t+k_{i}(1+t) d \log r+\frac{x_{i}}{w_{i}} d s-\frac{p_{A_{i}}}{w_{i}} d A-\frac{p_{G_{i}}}{w_{i}} d G\right]
$$

$$
d \log r=\frac{1}{r(1+t) B}\left[\sum_{i=1,2}\left(\frac{-1}{1-z_{i}} d \operatorname{Tax}_{i}+\frac{1}{1-z_{i}}\left(N_{i} p_{A_{i}} d A+N_{i} p_{G_{i}} d G\right)\right)-d \operatorname{Tax}_{F}+\left(-C_{A} X d A-C_{G} X d G\right)\right]
$$

where $B=L^{p}+\frac{N_{1} h_{1}}{1-z_{1}}+\frac{N_{2} h_{2}}{1-z_{2}}, d \operatorname{Tax}_{i}=N_{i} w_{i} d z_{i}+N_{i} h_{i} r d t+N_{i} x_{i} d s$, and $d \operatorname{Tax}_{F}=C_{s} X d s+L^{p} r d t$.

The first term on the right hand side of the rent equation (6), $(-1) /\left(1-z_{i}\right) d \operatorname{Tax}_{i}$, is the change in

total taxes collected from type $i$ individuals; the second term, $1 /\left(1-z_{i}\right)\left(N_{i} p_{A_{i}} d A+N_{i} p_{G_{i}} d G\right)$, is the change in the value of public services and amenities to individuals (with $p_{A}$ and $p_{G}$ indicating the partial derivatives of utility with respect to amenities and services, respectively); the third term, $d \operatorname{Tax}_{F}$, is the change in total taxes collected from firms; and the fourth term, $-C_{A} X d A-C_{G} X d G$, is the change in the value of amenities and public services to firms (with $C_{A}$ and $C_{G}$ indicating the partial derivatives of the cost function with respect to amenities and services, respectively). Both the first and third terms are negative, indicating that increases in total taxes collected from either households or firms result in 
proportionately lower rents per unit of land. The second and last terms are positive if public goods and amenities are productive $\left(C_{G}<0\right.$ and $\left.C_{A}<0\right)$. Thus, increases in the value of public goods or amenities to either households or firms increase rents per unit of land by an amount equal to the value of the public service or amenity per unit of land. Thus the positive value of amenities and of public goods is fully capitalized into land values. Differences between workers and firms in their valuation of local amenities, public goods, and taxes will be reflected in average wages (see Gyourko and Tracy, 1989).

\section{B. Construction of Metropolitan Areas}

Because geographic entities reported in the PUMS data change over time, consistent metropolitan areas are constructed following a methodology analogous to that used by Jaeger, Loeb, Turner, and Bound (1998). We use Jaeger et al.'s match of 1980 county groups and 1990 PUMAs as the starting point for our three-decade match. Because the composition of individual PUMAs differs from census to census and because these PUMAs differ from the county groups defined in the 1980 census, we evaluate the individual counties (or towns/boroughs in the case of New England) included in each PUMA or county group in order to make the closest possible match from year to year, regardless of the changing composition of PUMAs and county groups. We therefore begin by listing the counties (or parts thereof) included in each MSA in 1980 and 1990 according to Jaeger et al.’s definitions, noting any discrepancies between the two decades. We then examine the 2000 equivalency files to locate these counties according to the 2000 configuration of PUMAs and checked the equivalency files to determine whether the 2000 census had added any new areas to the definition of an MSA. If a new county (or counties) is identified with a particular MSA in 2000, these new areas (inconsistent with the 1980 and 1990 Jaeger et al. definitions) are included in our match if and only if it was possible to add these areas to the 1980 and 1990 matches. If only part of a PUMA had been identified as a new area associated with an MSA, this PUMA is considered for inclusion if and only if the majority of the population of that PUMA resided in the county (or town/borough) specifically tagged for the particular MSA. In other instances in which the assignment of a certain PUMA or county group to a given MSA is ambiguous, the location of the 
majority of the PUMA or county group’s population determines its allocation.

A list of low-choice metropolitan areas appears in Appendix Table 1. These metropolitan areas are selected because they are in the bottom third of school choice as measured by the index in Rothstein (2007). Most are fairly small Southern metropolitan areas. Each area is weighted equally in the analysis so as not to give undue importance to a few large metropolitan areas.

\section{Matching of Revenue and Expenditure Data to Metropolitan Areas}

The Census of Governments reports fiscal information for the following levels of governments: state, county, school district, city, town, and special district. We use years 1977, 1987, and 1997 to match to Census years 1980, 1990, and 2000. States are larger than a metropolitan area in most cases; therefore, state revenues and expenditures are allocated to the metropolitan area in proportion to the metropolitan area's representation in the state population. Metropolitan areas that cross state lines are allocated state revenues and expenditures from all relevant states. For all other levels of government, the Census of Governments identifies the "primary county" of the governmental unit. Since metropolitan areas are composed of counties, we use the primary county to assign revenues and expenditures. We then calculate revenues and expenditures, convert to 2000 dollars, and divide by the metropolitan area population. The final measures reflect per capita revenues and expenditures for each metropolitan area and year.

\section{Fees and Charges}

Fees and charges represent roughly a quarter of all revenues in the sample. The main results reported in the paper treat fees and charges analogously to other tax revenues. We believe that individuals consider mandatory fees and charges like other taxes in making a migration decision. Ideally, we would be able to separate fees and charges that operate like a head tax from those that are more analogous to a discretionary fee-for-service payment. Since we cannot do this, we explore the sensitivity of our analysis to omitting fees and charges completely.

As shown in Appendix Table 2, the results are somewhat sensitive to this change. For the most 
part, the sign and magnitude of the remaining revenue variables is quite similar. The coefficients on expenditures change substantially in some cases, suggesting that expenditures for some categories are correlated with fees and charges. The fiscal variables are no longer jointly significant, though in some specifications either the tax variables or the expenditure variables are jointly significant.

\section{E. Results from the Full Sample}

The regression tables and figures in the paper present results from the "low-choice" sample. The results are somewhat sensitive to including the full set of areas is incorporated into the analysis, as shown in Appendix Table 3. Notably, the effect of property tax revenue on inequality is muted relative to the results from the low choice sample (see Table 3) and never statistically significant. Sales taxes, on the other hand, are positive and statistically significant; this sign is opposite to what one would predict if sales taxes are regressive. Education has a positive association with inequality in the full sample. Overall, revenue variables are a significant predictor of inequality in all three models and the fiscal variables are statistically significant in two of three models.

We have privileged the results from the low-choice sample. This is because our theoretical model assumes fiscal environments are homogenous within cities; if the land market and the labor market can be easily separated then many of the adjustments described in the model can occur by workers moving within a metropolitan area and wages may not adjust as described. Our data also do not allow us to observe differences in taxes and expenditures within metropolitan areas which may be quite pronounced. For these reasons, the results from the full sample should be interpreted with caution.

\section{Endnote.}

We are grateful to Chris Briem, Dianne Pfundstein, Zoe Xie, and Jenny Ying for superb data assistance and to the Joint Center for Poverty Research and the National Science Foundation for funding. We are indebted to Chris Cunningham, participants in the Society of Labor Economists annual meeting, the Regional Science and Urban Economics meeting, the Williams College Brown Bag Lunch series, and the Public Finance Review conference at Georgia State University for helpful comments. 


\section{References}

Albouy, David. 2009. “The Unequal Burden of Federal Taxation.” Journal of Political Economy 117(4): 635-667.

Alesina, Alberto, Edward L. Glaeser, and Bruce Sacerdote. 2001. "Why Doesn't the United States Have A European Welfare State?” Brookings Paper on Economic Activity 2: 187-254.

Bartik, Timothy J. 1996. "The Distributional Effects of Local Labor Demand and Industrial Mix: Estimates Using Individual Panel Data." Journal of Urban Economics 40: 150-178.

Beeson, Patricia E. 1991. "Amenities and Regional Differences in Returns to Worker Characteristics." Journal of Urban Economics 30: 224-241.

Borjas, George J. and Valerie A. Ramey. 1995. "Foreign Competition, Market Power, and Wage Inequality." Quarterly Journal of Economics 110: 1075-1110.

Cloutier, Norman R. 1997. "Metropolitan Income Inequality During the 1980s: The Impact of Urban Development, Industrial Mix, and Family Structure." Journal of Regional Science 37, no. 3: 459478.

Farber, Stephen and Robert Newman. 1987. “Accounting for South/Non-South Real Wage Differentials and for Changes in Those Differentials Over Time.” Review of Economics and Statistics 69: 215223.

Feldstein, Martin and Marian Vaillant Wrobel. 1998. “Can State Taxes Redistribute Income?” Journal of Public Economics 68: 369-396.

Gyourko, Joseph and Joseph Tracy. 1989. "The Importance of Local Fiscal Conditions in Analyzing Local Labor Markets." Journal of Political Economy 97: 1208-1231.

and __ 1991. "The Structure of Local Public Finance and the Quality of Life." Journal of Political Economy 99: 774-806.

Glaeser, Edward L., Matthew E. Kahn, and Jordan Rappaport. 2008. "Why Do the Poor Live in Cities?

The Role of Public Transportation.” Journal of Urban Economics 63: 1-24.

Glaeser, Edward L. and Joshua D. Gottlieb. 2009. "The Wealth of Cities: Agglomeration Economies and Spatial Equilibrium in the United States.” Journal of Economic Literature 47(4) : 983-1028.

Hanushek, Eric. 1973. "Regional Differences in the Structure of Earnings." Review of Economics and Statistics 55: 204-213.

Helms, L. Jay. 1985. “The Effect of State and Local Taxes on Economic Growth.” Review of Economics and Statistics 67(4): 574-582.

Jaeger, David A., Susanna Loeb, Sarah E. Turner, and John Bound. 1998. “Coding Geographic Areas Across Census Years: Creating Consistent Definitions of Metropolitan Areas.” NBER Working Paper No. W6772. 
Levernier, William, Mark D. Partridge, and Dan S. Rickman. 1998. "Differences in Metropolitan and Nonmetropolitan U.S. Family Income Inequality: A Cross-County Comparison." Journal of Urban Economics 44: 272-290.

McCall, Leslie. 2000. "Explaining Levels of Within-Group Inequality in U.S. Labor Markets." Demography 37: 415-430.

Moretti, Enrico. 2008. “Real Wage Inequality.” NBER Working Paper No. W14370.

Reed, Deborah. 2001. "Immigration and Males' Earnings Inequality in the Regions of the United States.” Demography 38: 363-73.

Roback, Jennifer. 1982. “Wages, Rents, and the Quality of Life.” Journal of Political Economy 90: 1257-1278.

Rosenberg, Carol. 2007. “State Individual Income Tax Progressivity.” Tax Policy Center Tax Notes, March 26, 2007.

Rothstein, Jesse. 2007. "Does Competition Among Public Schools Benefit Students and Taxpayers? Comment," American Economic Review 97(5): 2026-2037.

Sahling, LeonardG. and Sharon P. Smith. 1983. "Regional Wage Differentials: Has the South Risen Again?” Review of Economics and Statistics 65: 131-135.

Sanchez, Thomas W. 2002. “The Impact of Public Transport on U.S. Wage Inequality.” Urban Studies 39: 423-436.

Volscho, Thomas W. and Andrew S. Fullerton. 2005. "Metropolitan Earnings Inequality: Union and Government-Sector Employment Effects.” Social Science Quarterly 86:1324-37.

Wheeler, Christopher. 2004. "On the Distributional Aspects of Urban Growth.” Journal of Urban Economics 55: 371-397. 


\section{Author Biographies}

Patricia Beeson is the Vice Provost for Graduate and Undergraduate Studies and Professor of Economics and Public Policy at the University of Pittsburgh. She received a B.S. in Economics from Oregon State University, and a Ph.D. in Economics from the University of Oregon. Her research has focused on urban economics, in particular on aspects of labor markets in metropolitan areas, the historical development of American cities, and mortgage lending.

Lara Shore-Sheppard is Associate Professor of Economics at Williams College and a Faculty Research Fellow at the National Bureau of Economic Research. She received a B.A. magna cum laude from Amherst College and a Ph.D. in Economics from Princeton University. Much of her research has assessed the impact of publicly-provided health insurance for low-income children, focusing particularly on the interaction between public insurance and private insurance, cash welfare programs, and employment. She has also worked on wage distributions in metropolitan areas, welfare and employment dynamics of less-skilled women, and measurement issues in the Survey of Income and Program Participation.

Tara Watson is an assistant professor in the Economics department at Williams College and a Faculty Research Fellow at the National Bureau of Economic Research. She received her B.A. from Wesleyan University and Ph.D. in Economics from Harvard University. Her research centers on the areas of urban economics, health economics, and economic demography. 
Table 1. WageStructures Across Metropolitan Areas

\begin{tabular}{|c|c|c|c|c|c|c|c|c|c|c|c|c|}
\hline & \multicolumn{4}{|c|}{$1980(\mathrm{~N}=131)$} & \multicolumn{4}{|c|}{$1990(\mathrm{~N}=131)$} & \multicolumn{4}{|c|}{$2000(N=131)$} \\
\hline & Mean & SD & Min & $\operatorname{Max}$ & Mean & SD & Min & Max & Mean & SD & Min & Max \\
\hline 90th percentile wage & 30.279 & 3.054 & 21.102 & 41.252 & 30.762 & 3.425 & 21.365 & 42.062 & 32.478 & 4.213 & 22.527 & 49.097 \\
\hline 50th percentile wage & 17.332 & 2.620 & 9.723 & 23.319 & 16.270 & 2.282 & 9.244 & 22.255 & 15.952 & 2.020 & 9.442 & 22.196 \\
\hline 10th percentile wage & 8.393 & 1.477 & 5.137 & 12.105 & 7.604 & 1.146 & 4.674 & 11.350 & 7.658 & 0.978 & 4.681 & 9.939 \\
\hline Log(90th) - Log(10th) (90-10 Wage Gap) & 1.289 & 0.142 & 1.015 & 1.690 & 1.398 & 0.114 & 1.128 & 1.677 & 1.444 & 0.118 & 1.134 & 1.793 \\
\hline Median Decile 2 Premium & -0.353 & 0.116 & -0.591 & -0.027 & -0.425 & 0.117 & -0.722 & -0.119 & -0.429 & 0.096 & -0.668 & -0.202 \\
\hline Median Decile 9 Premium & 0.295 & 0.088 & -0.014 & 0.498 & 0.273 & 0.089 & -0.016 & 0.494 & 0.294 & 0.086 & 0.084 & 0.545 \\
\hline Dec 9 Premium-Dec 2 Premium (Decile Premium Gap) & 0.648 & 0.075 & 0.476 & 0.872 & 0.698 & 0.085 & 0.462 & 0.927 & 0.723 & 0.073 & 0.531 & 0.935 \\
\hline Median High School Wage & 16.496 & 2.747 & 8.354 & 22.812 & 14.366 & 2.115 & 8.332 & 20.697 & 13.810 & 1.585 & 8.994 & 16.918 \\
\hline Median College Wage & 21.696 & 2.062 & 15.970 & 27.374 & 21.242 & 1.978 & 14.688 & 25.704 & 21.390 & 2.136 & 14.312 & 27.828 \\
\hline Estimated Return to College & 0.343 & 0.068 & 0.128 & 0.493 & 0.434 & 0.058 & 0.244 & 0.569 & 0.464 & 0.064 & 0.299 & 0.626 \\
\hline Median High School Premium & 0.012 & 0.124 & -0.362 & 0.298 & -0.033 & 0.114 & -0.393 & 0.233 & -0.033 & 0.095 & -0.295 & 0.187 \\
\hline Median College Premium & -0.027 & 0.084 & -0.297 & 0.179 & -0.064 & 0.095 & -0.337 & 0.175 & -0.093 & 0.097 & -0.383 & 0.209 \\
\hline College Premium-High School Premium (Education Premium Gap) & -0.039 & 0.077 & -0.243 & 0.137 & -0.031 & 0.073 & -0.231 & 0.189 & -0.059 & 0.071 & -0.263 & 0.155 \\
\hline
\end{tabular}


Table 2. Means of Variables Used in Analysis

\begin{tabular}{|c|c|c|c|c|c|c|}
\hline & \multicolumn{3}{|c|}{ Full Sample ( $N=131$ each year) } & \multicolumn{3}{|c|}{ Low-Choice Sample ( $\mathrm{N}=44$ each year; } \\
\hline & 1980 & 1990 & 2000 & 1980 & 1990 & 2000 \\
\hline \multicolumn{7}{|l|}{ Wage Inequality } \\
\hline $\log (90$ th) $-\log (10 \mathrm{th})$ (90-10 Wage Gap) & 1.289 & 1.398 & 1.444 & 1.357 & 1.442 & 1.472 \\
\hline Dec 9 Premium-Dec 2 Premium (Decile Premium Gap) & 0.648 & 0.698 & 0.723 & 0.691 & 0.735 & 0.747 \\
\hline College Premium-High School Premium (Education Premium Gap) & -0.039 & -0.031 & -0.059 & -0.014 & -0.013 & -0.049 \\
\hline \multicolumn{7}{|l|}{ Fiscal Characteristics } \\
\hline Total Taxes Per Capita, $\$ 000$ & 2.858 & 3.325 & 3.817 & 2.490 & 2.939 & 3.488 \\
\hline Property Taxes Per Capita, $\$ 000$ & 0.666 & 0.657 & 0.767 & 0.501 & 0.522 & 0.643 \\
\hline Sales Taxes Per Capita, $\$ 000$ & 0.756 & 0.881 & 1.013 & 0.794 & 0.949 & 1.108 \\
\hline Income Taxes Per Capita, $\$ 000$ & 0.299 & 0.437 & 0.548 & 0.165 & 0.253 & 0.339 \\
\hline User Fees and Charges Per Capita, $\$ 000$ & 0.645 & 0.901 & 1.009 & 0.625 & 0.849 & 0.993 \\
\hline Social Insurance Taxes Per Capita, $\$ 000$ & 0.206 & 0.140 & 0.162 & 0.146 & 0.092 & 0.106 \\
\hline Other Taxes Per Capita, $\$ 000$ & 0.287 & 0.309 & 0.318 & 0.259 & 0.274 & 0.298 \\
\hline Total Expenditure Per Capita, $\$ 000$ & 3.663 & 4.323 & 5.175 & 3.223 & 3.932 & 4.780 \\
\hline Infrastructure Exp Per Capita, $\$ 000$ & 0.792 & 0.944 & 0.969 & 0.731 & 0.907 & 0.955 \\
\hline Public Safety Exp Per Capita, $\$ 000$ & 0.223 & 0.292 & 0.387 & 0.215 & 0.283 & 0.382 \\
\hline Education Exp Per Capita, $\$ 000$ & 1.214 & 1.338 & 1.604 & 1.082 & 1.214 & 1.436 \\
\hline Health Exp Per Capita, $\$ 000$ & 0.272 & 0.323 & 0.400 & 0.271 & 0.320 & 0.402 \\
\hline Social Welfare Exp Per Capita, $\$ 000$ & 0.569 & 0.580 & 0.885 & 0.397 & 0.428 & 0.748 \\
\hline Other Exp Per Capita, $\$ 000$ & 0.593 & 0.846 & 0.930 & 0.526 & 0.779 & 0.856 \\
\hline \multicolumn{7}{|l|}{ Other CMSA Characteristics } \\
\hline CMSA Population & $1,243,762$ & $1,390,357$ & $1,590,220$ & 983,454 & $1,099,904$ & $1,267,858$ \\
\hline Unemployment Rate & 0.044 & 0.046 & 0.042 & 0.040 & 0.047 & 0.042 \\
\hline Northeast & 0.176 & 0.176 & 0.176 & 0.023 & 0.023 & 0.023 \\
\hline Midwest & 0.214 & 0.214 & 0.214 & 0.091 & 0.091 & 0.091 \\
\hline South & 0.420 & 0.420 & 0.420 & 0.727 & 0.727 & 0.727 \\
\hline West & 0.191 & 0.191 & 0.191 & 0.159 & 0.159 & 0.159 \\
\hline Industry Share - Agriculture and Natural Resources & 0.035 & 0.030 & 0.023 & 0.045 & 0.035 & 0.027 \\
\hline Industry Share - Construction & 0.080 & 0.087 & 0.100 & 0.099 & 0.100 & 0.111 \\
\hline Industry Share - Manufacturing & 0.319 & 0.271 & 0.236 & 0.254 & 0.227 & 0.199 \\
\hline Industry Share - Transportation, Utilities, Etc. & 0.113 & 0.108 & 0.107 & 0.119 & 0.114 & 0.112 \\
\hline Industry Share - Retail and Wholesale Trade & 0.171 & 0.189 & 0.188 & 0.182 & 0.197 & 0.195 \\
\hline Industry Share - FIRE & 0.044 & 0.047 & 0.046 & 0.046 & 0.047 & 0.042 \\
\hline Industry Share - Services (except professional services) & 0.054 & 0.073 & 0.094 & 0.067 & 0.084 & 0.101 \\
\hline Industry Share - Professional Services & 0.105 & 0.120 & 0.135 & 0.103 & 0.117 & 0.133 \\
\hline Industry Share - Public Administration & 0.080 & 0.074 & 0.071 & 0.085 & 0.080 & 0.079 \\
\hline Fraction Immigrant & 0.052 & 0.070 & 0.108 & 0.056 & 0.077 & 0.118 \\
\hline Fraction Non-Hispanic Black & 0.079 & 0.082 & 0.088 & 0.107 & 0.107 & 0.117 \\
\hline Fraction Hispanic & 0.060 & 0.074 & 0.106 & 0.082 & 0.097 & 0.131 \\
\hline Fraction Other Race & 0.017 & 0.023 & 0.044 & 0.022 & 0.026 & 0.046 \\
\hline Fraction No High School & 0.085 & 0.039 & 0.032 & 0.096 & 0.044 & 0.036 \\
\hline Fraction Some High School & 0.125 & 0.101 & 0.090 & 0.130 & 0.112 & 0.102 \\
\hline Fraction Some College & 0.196 & 0.304 & 0.317 & 0.198 & 0.306 & 0.323 \\
\hline Fraction College Grad & 0.113 & 0.166 & 0.179 & 0.109 & 0.156 & 0.166 \\
\hline Fraction Post-Graduate & 0.093 & 0.081 & 0.090 & 0.085 & 0.074 & 0.083 \\
\hline Heating Degree Days & 4039.520 & 4039.778 & 4039.956 & 2513.536 & 2513.642 & 2513.681 \\
\hline Cooling Degree Days & 1542.847 & 1542.841 & 1542.806 & 2349.114 & 2349.018 & 2348.946 \\
\hline Violent Crimes Per Capita & 0.006 & 0.007 & 0.005 & 0.006 & 0.008 & 0.006 \\
\hline Property Crimes Per Capita & 0.058 & 0.055 & 0.042 & 0.061 & 0.063 & 0.048 \\
\hline Population Density & 309.834 & 343.712 & 376.972 & 255.698 & 300.588 & 349.005 \\
\hline Number of Museums (if avail.) & 8.553 & 15.821 & 25.507 & 7.435 & 13.069 & 20.386 \\
\hline Restaurants Per Capita & 0.001 & 0.002 & 0.002 & 0.001 & 0.002 & 0.002 \\
\hline Missing Museum Information & 0.076 & 0.015 & 0.008 & 0.114 & 0.023 & 0.000 \\
\hline
\end{tabular}


Table 3. Effect of Fiscal Characteristics on Wage Dispersion Pooled Low-Choice Sample

\begin{tabular}{|c|c|c|c|}
\hline & 90-10 Wage Gap & Decile Premium Gap & Education Premium Gap \\
\hline \multirow[t]{2}{*}{ Log (Total Tax in 000s) } & -0.215 & $-0.324+$ & -0.209 \\
\hline & $(0.180)$ & $(0.179)$ & $(0.133)$ \\
\hline \multirow[t]{2}{*}{ Log (Prop Tax in 000s) } & 0.0520 & 0.0452 & $0.0708^{*}$ \\
\hline & $(0.0331)$ & $(0.0431)$ & $(0.0280)$ \\
\hline \multirow[t]{2}{*}{ Log (Sales Tax in 000s) } & -0.0363 & 0.0641 & 0.0307 \\
\hline & $(0.0423)$ & $(0.0509)$ & $(0.0445)$ \\
\hline \multirow[t]{2}{*}{ Log (User Fees and Charges in 000s) } & 0.00267 & 0.00721 & 0.0271 \\
\hline & $(0.0597)$ & $(0.0507)$ & $(0.0561)$ \\
\hline \multirow[t]{2}{*}{ Log (Social Insuance Tax) } & 0.00617 & -0.00273 & 0.00565 \\
\hline & $(0.0231)$ & $(0.0192)$ & $(0.0175)$ \\
\hline \multirow[t]{2}{*}{ Log (Other Tax) } & 0.0253 & 0.0239 & -0.0285 \\
\hline & $(0.0396)$ & $(0.0378)$ & $(0.0372)$ \\
\hline \multirow[t]{2}{*}{ Log (Infrastructure Expenditure in 000s) } & 0.0567 & 0.0203 & 0.0283 \\
\hline & $(0.0370)$ & $(0.0357)$ & $(0.0386)$ \\
\hline \multirow[t]{2}{*}{ Log (Public Safety Expenditure in 000s) } & -0.0567 & -0.0549 & -0.0254 \\
\hline & $(0.0530)$ & $(0.0577)$ & $(0.0486)$ \\
\hline \multirow[t]{2}{*}{ Log (Education Expenditure in 000s) } & 0.00586 & -0.000695 & 0.114 \\
\hline & $(0.106)$ & $(0.0780)$ & $(0.120)$ \\
\hline \multirow[t]{2}{*}{ Log (Health Expenditure in 000s) } & 0.00563 & 0.0316 & -0.00795 \\
\hline & $(0.0240)$ & $(0.0267)$ & $(0.0312)$ \\
\hline \multirow[t]{2}{*}{ Log (Social Insurance Expenditure in 000s] } & 0.0711 & 0.00632 & 0.0215 \\
\hline & $(0.0484)$ & $(0.0387)$ & $(0.0455)$ \\
\hline \multirow[t]{2}{*}{ Log (Other Expenditure in 000s) } & -0.0262 & $0.100 * *$ & 0.0128 \\
\hline & $(0.0379)$ & $(0.0352)$ & $(0.0298)$ \\
\hline Controls for Population and Demographic Mix & yes & yes & yes \\
\hline Region Dummies & yes & yes & yes \\
\hline Year Dummies & yes & yes & yes \\
\hline Demand Controls & yes & yes & yes \\
\hline Ammenities Controls & yes & yes & yes \\
\hline Number of Observations & 132 & 132 & 132 \\
\hline Number of Metropolitan Areas & 44 & 44 & 44 \\
\hline R-Squared & 0.84 & 0.66 & 0.64 \\
\hline P-value from F-test on Fiscal Variables & 0.11 & 0.01 & 0.06 \\
\hline P-value from F-test on Tax Variables & 0.50 & 0.26 & 0.05 \\
\hline P-value on F-test on Expenditure Variables & 0.30 & 0.04 & 0.71 \\
\hline
\end{tabular}

Note: Standard errors in parantheses are clustered by CMSA. $+,{ }^{*}, * \star$ refer to statistical significance at the 10,5 , and 1 percent levels respectively. The 90-10 Gap is the 90th percentile log wage minus the 10th percentile log wage. The Decile Premium is the median residual in the ninth decile of the CMSA-year cell minus the median residual in the second decile. The Education Premium is the median residual of college graduates miuns the median residual of high school graduates. See text for details about control variables. 


\title{
Appendix Table 1. Metropolitan Areas in The Low Choice Sample
}

\author{
Albuquerque, NM \\ Augusta, GA \\ Baton Rouge, LA \\ Brownsville-Harlingen, TX \\ Charleston, SC \\ Charleston, WV \\ Corpus Christi, TX \\ Daytona Beach, FL \\ El Paso, TX \\ Evansville, IN-KY \\ Fayetteville, NC \\ Fort Myers-Cape Coral, FL \\ Fort Pierce, FL \\ Fort Wayne, IN \\ Fresno, CA \\ Greenville-Spartanburg, SC \\ Honolulu, $\mathrm{HI}$ \\ Jackson, MS \\ Jacksonville, FL \\ Knoxville, TN \\ Lakeland-Winter Haven, FL \\ Las Vegas, NV \\ Lexington-Fayette, $\mathrm{KY}$ \\ Louisville, KY-IN \\ Macon-Warner Robins, GA \\ Melbourne-Titusville-Palm Bay, FL \\ Memphis, TN-AR-MS \\ Miami-Fort Lauderdale, FL \\ Mobile, AL \\ Montgomery, AL \\ New Orleans, LA \\ NY-Northern NJ-Long Island, NY-NJ-CT \\ Orlando, FL \\ Pensacola, FL \\ Provo-Orem, UT \\ Raleigh-Durham, NC \\ Reno, NV \\ Rockford, IL \\ Sarasota, FL \\ Shreveport, LA \\ Tampa-St. Petersburg-Clearwater, FL \\ Tucson, AZ \\ West Palm Beach-Boca Raton-Delray, FL \\ Wichita, KS
}

Note: There are 44 metropolitan areas in the low-choice sample; they are those in the lowest third of school district choice. Regression analyses weight each metropolitan area equally. 
Appendix Table 2. Analysis Excluding Fees and Charges

\begin{tabular}{|c|c|c|c|}
\hline & $\begin{array}{c}\text { Exclude Charges/Fees } \\
\text { 90-10 Wage Gap }\end{array}$ & $\begin{array}{l}\text { Exclude Charges/Fees } \\
\text { Decile Premium Gap }\end{array}$ & $\begin{array}{l}\text { Exclude Charges/Fees } \\
\text { Education Premium Gap }\end{array}$ \\
\hline \multirow[t]{2}{*}{ Log (Total Non-Fee Tax in 000s) } & -0.143 & -0.187 & -0.159 \\
\hline & $(0.137)$ & $(0.132)$ & $(0.121)$ \\
\hline \multirow[t]{2}{*}{ Log (Prop Tax in 000s) } & 0.0494 & 0.0370 & $0.0705^{\star}$ \\
\hline & $(0.0323)$ & $(0.0404)$ & $(0.0285)$ \\
\hline \multirow[t]{2}{*}{ Log (Sales Tax in 000s) } & -0.0212 & 0.0833 & 0.0396 \\
\hline & $(0.0433)$ & $(0.0525)$ & $(0.0427)$ \\
\hline \multicolumn{4}{|l|}{ Log (User Fees and Charges in 000s) } \\
\hline \multirow[t]{2}{*}{ Log (Social Insuance Tax) } & 0.0153 & 0.0100 & 0.0110 \\
\hline & $(0.0203)$ & $(0.0185)$ & $(0.0172)$ \\
\hline \multirow[t]{2}{*}{ Log (Other Tax) } & 0.0317 & 0.0302 & -0.0230 \\
\hline & $(0.0391)$ & $(0.0380)$ & $(0.0380)$ \\
\hline \multirow[t]{2}{*}{ Log (Infrastructure Expenditure in 000s) } & 0.00768 & $-0.0505^{\star}$ & -0.00234 \\
\hline & $(0.0169)$ & $(0.0199)$ & $(0.0214)$ \\
\hline \multirow[t]{2}{*}{ Log (Public Safety Expenditure in 000s) } & -0.0623 & -0.0632 & -0.0275 \\
\hline & $(0.0513)$ & $(0.0579)$ & $(0.0479)$ \\
\hline \multirow[t]{2}{*}{ Log (Education Expenditure in 000s) } & -0.0245 & -0.0477 & 0.102 \\
\hline & $(0.0981)$ & $(0.0716)$ & $(0.112)$ \\
\hline \multirow[t]{2}{*}{ Log (Health Expenditure in 000s) } & -0.0168 & -0.000801 & -0.0205 \\
\hline & $(0.0132)$ & $(0.0206)$ & $(0.0175)$ \\
\hline \multirow[t]{2}{*}{ Log (Social Insurance Expenditure in 000s) } & 0.0566 & -0.0179 & 0.0140 \\
\hline & $(0.0454)$ & $(0.0368)$ & $(0.0473)$ \\
\hline \multirow[t]{2}{*}{ Log (Other Expenditure in 000s) } & -0.0202 & $0.106^{*}$ & 0.0180 \\
\hline & $(0.0402)$ & $(0.0404)$ & $(0.0307)$ \\
\hline Controls for Population and Demographic Mix & yes & yes & yes \\
\hline Region Dummies & yes & yes & yes \\
\hline Year Dummies & yes & yes & yes \\
\hline Demand Controls & yes & yes & yes \\
\hline Ammenities Controls & yes & yes & yes \\
\hline Number of Observations & 132 & 132 & 132 \\
\hline Number of Metropolitan Areas & 44 & 44 & 44 \\
\hline R-Squared & 0.839 & 0.648 & 0.643 \\
\hline P-value from F-test on Fiscal Variables & 0.21 & 0.30 & 0.04 \\
\hline P-value from F-test on Tax Variables & 0.65 & 0.59 & 0.02 \\
\hline P-value on F-test on Expenditure Variables & 0.47 & 0.03 & 0.81 \\
\hline
\end{tabular}




\section{Appendix Table 3. Effect of Fiscal Characteristics on Wage Dispersion Full Sample}

\begin{tabular}{|c|c|c|c|}
\hline & 90-10 Wage Gap & Decile Premium Gap & Education Premium Gap \\
\hline Log (Total Tax in 000s) & $\begin{array}{l}-0.102 \\
(0.119)\end{array}$ & $\begin{array}{l}-0.171 \\
(0.114)\end{array}$ & $\begin{array}{c}\mathbf{0 . 0 4 2 6} \\
(0.0934)\end{array}$ \\
\hline Log (Prop Tax in 000s) & $\begin{array}{c}0.0198 \\
(0.0218)\end{array}$ & $\begin{array}{c}0.0142 \\
(0.0240)\end{array}$ & $\begin{array}{l}\mathbf{0 . 0 0 2 2 1} \\
(0.0160)\end{array}$ \\
\hline Log (Sales Tax in 000s) & $\begin{array}{l}\mathbf{0 . 0 5 6 8 +} \\
(0.0312)\end{array}$ & $\begin{array}{l}0.0667^{\star *} \\
(0.0186)\end{array}$ & $\begin{array}{c}0.0335 \\
(0.0248)\end{array}$ \\
\hline Log (User Fees and Charges in 000s) & $\begin{array}{l}\mathbf{0 . 0 0 6 1 8} \\
(0.0281)\end{array}$ & $\begin{array}{l}\mathbf{0 . 0 0 7 2 6} \\
(0.0250)\end{array}$ & $\begin{array}{l}\mathbf{0 . 0 0 4 7 2} \\
(0.0265)\end{array}$ \\
\hline Log (Social Insuance Tax) & $\begin{array}{l}\mathbf{0 . 0 2 6 4 +} \\
(0.0135)\end{array}$ & $\begin{array}{l}\mathbf{0 . 0 2 7 1 * *} \\
(0.0102)\end{array}$ & $\begin{array}{l}-0.00721 \\
(0.0107)\end{array}$ \\
\hline Log (Other Tax) & $\begin{array}{c}-0.0293 \\
(0.0186)\end{array}$ & $\begin{array}{c}-0.000202 \\
(0.0203)\end{array}$ & $\begin{array}{c}-0.0506 * * \\
(0.0168)\end{array}$ \\
\hline Log (Infrastructure Expenditure in 000s) & $\begin{array}{c}0.0358 \\
(0.0253)\end{array}$ & $\begin{array}{l}\mathbf{0 . 0 0 8 3 1} \\
(0.0209)\end{array}$ & $\begin{array}{l}-0.0230 \\
(0.0233)\end{array}$ \\
\hline Log (Public Safety Expenditure in 000s) & $\begin{array}{l}-0.0196 \\
(0.0343)\end{array}$ & $\begin{array}{c}0.0135 \\
(0.0297)\end{array}$ & $\begin{array}{c}-0.0132 \\
(0.0325)\end{array}$ \\
\hline Log (Education Expenditure in 000s) & $\begin{array}{c}\mathbf{0 . 0 3 6 9} \\
(0.0573)\end{array}$ & $\begin{array}{c}0.0349 \\
(0.0494)\end{array}$ & $\begin{array}{c}0.0405 \\
(0.0523)\end{array}$ \\
\hline Log (Health Expenditure in 000s) & $\begin{array}{c}\mathbf{0 . 0 1 8 1} \\
(0.0144)\end{array}$ & $\begin{array}{l}\mathbf{0 . 0 2 9 3}^{\boldsymbol{*}} \\
(0.0132)\end{array}$ & $\begin{array}{l}\mathbf{0 . 0 0 4 5 7} \\
(0.0136)\end{array}$ \\
\hline Log (Social Insurance Expenditure in 000s) & $\begin{array}{c}-0.0178 \\
(0.0260)\end{array}$ & $\begin{array}{c}-0.0376+ \\
(0.0202)\end{array}$ & $\begin{array}{c}\mathbf{0 . 0 1 4 0} \\
(0.0219)\end{array}$ \\
\hline Log (Other Expenditure in 000s) & $\begin{array}{c}-0.0210 \\
(0.0291)\end{array}$ & $\begin{array}{l}0.0644^{*} \\
(0.0250)\end{array}$ & $\begin{array}{c}-0.0291 \\
(0.0251)\end{array}$ \\
\hline Controls for Population and Demographic Mix & yes & yes & yes \\
\hline Region Dummies & yes & yes & yes \\
\hline Year Dummies & yes & yes & yes \\
\hline Demand Controls & yes & yes & yes \\
\hline Ammenities Controls & yes & yes & yes \\
\hline Number of Observations & 393 & 393 & 393 \\
\hline Number of Metropolitan Areas & 131 & 131 & 131 \\
\hline R-Squared & 0.798 & 0.584 & 0.474 \\
\hline P-value from F-test on Fiscal Variables & 0.19 & 0.00 & 0.06 \\
\hline P-value from F-test on Tax Variables & 0.03 & 0.00 & 0.02 \\
\hline P-value on F-test on Expenditure Variables & 0.47 & 0.01 & 0.28 \\
\hline
\end{tabular}

Note: Standard errors in parantheses are clustered by CMSA. +, *, ** refer to statistical significance at the 10, 5, and 1 percent levels respectively. The 90-10 Gap is the 90th percentile log wage minus the 10th percentile log wage. The Decile Premium is the median residual in the ninth decile of the CMSA-year cell minus the median residual in the second decile. The Education Premium is the median residual of college graduates miuns the median residual of high school graduates. See text for details about control variables. 
Figure 1. Log Wage Distributions in Selected Metro Areas, 2000
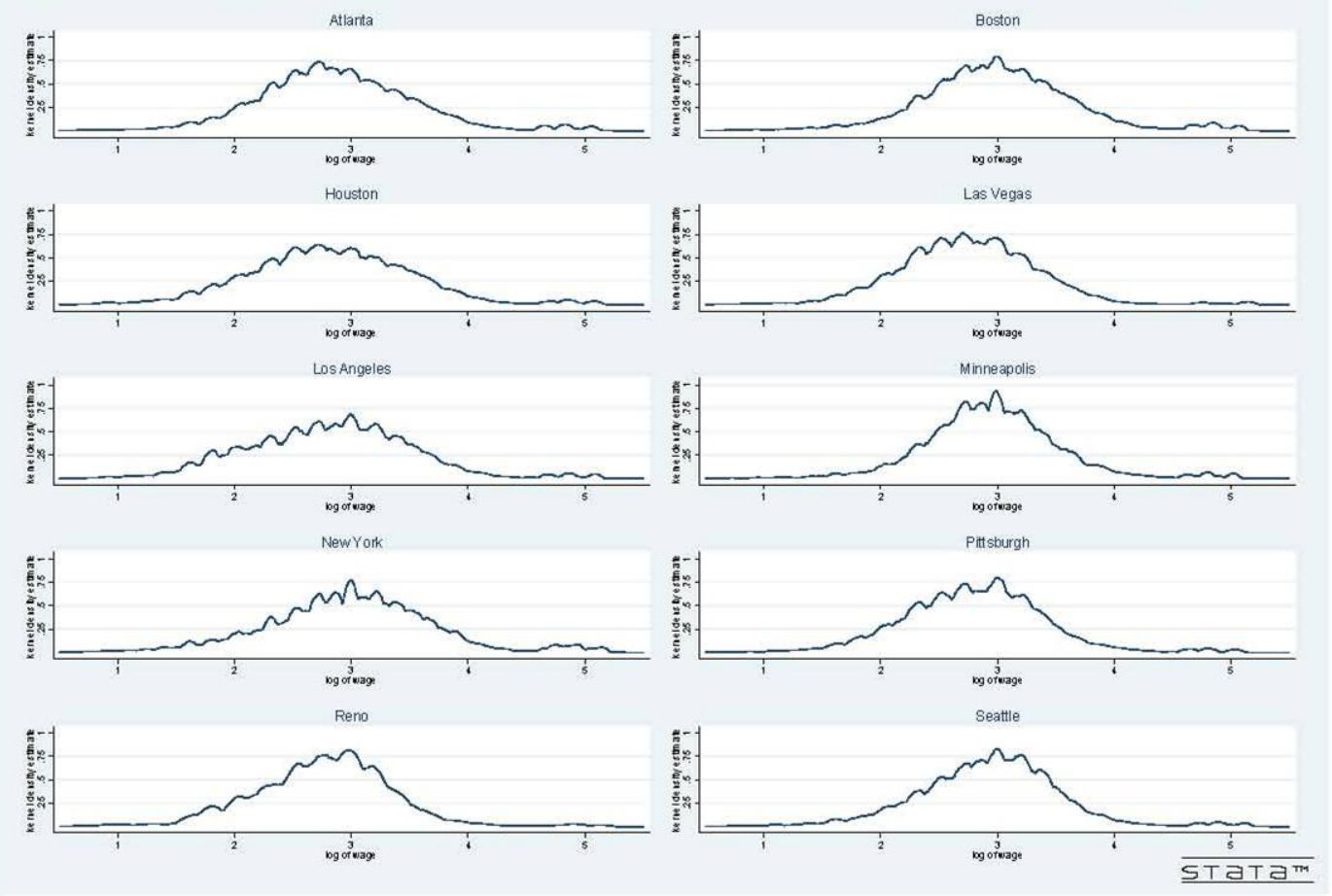

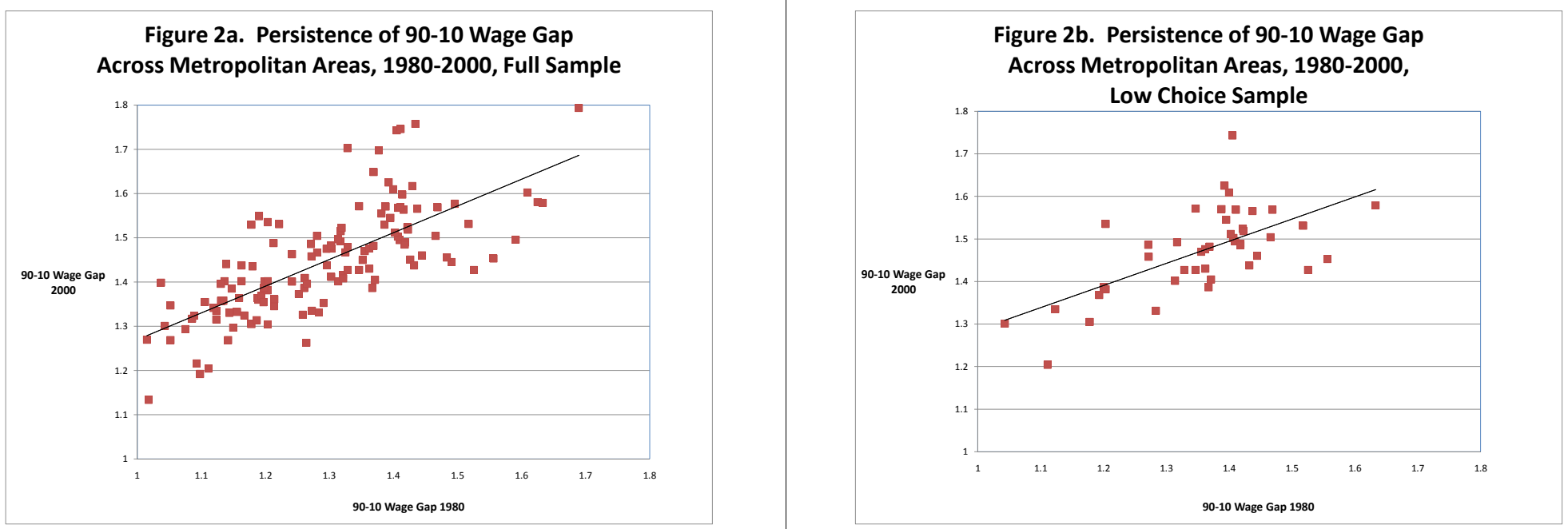

Figure 3a. Persistence of Decile Premium Gap Across Metropolitan Areas, 1980-2000, Full Sample

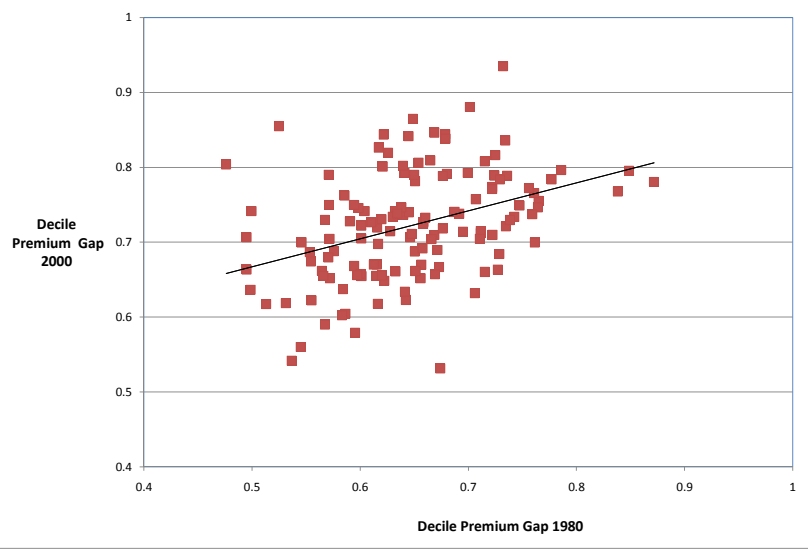

Figure 3b. Persistence of Decile Premium Gap Across Metropolitan Areas, 1980-2000, Low Choice Sample

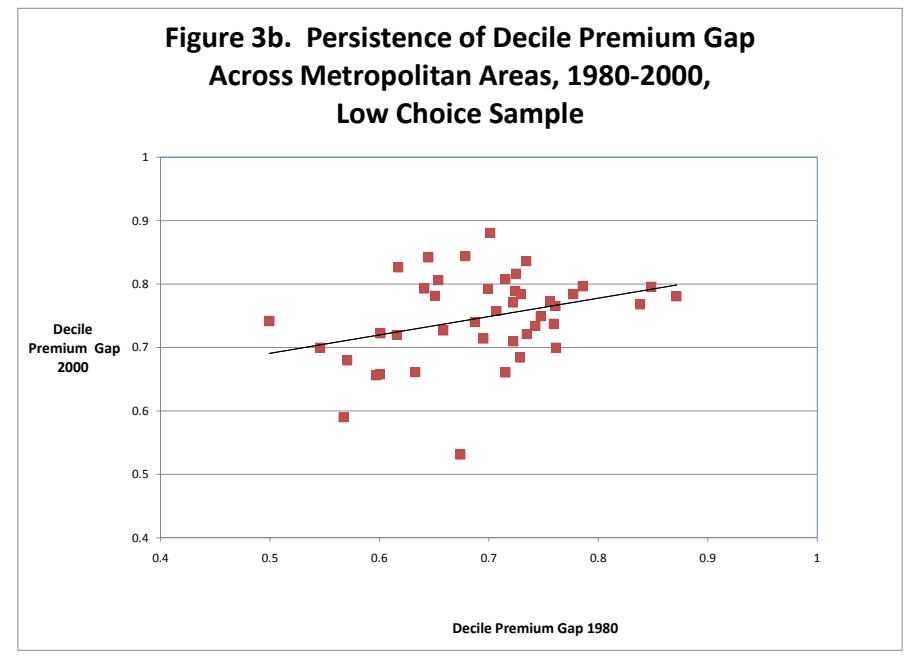

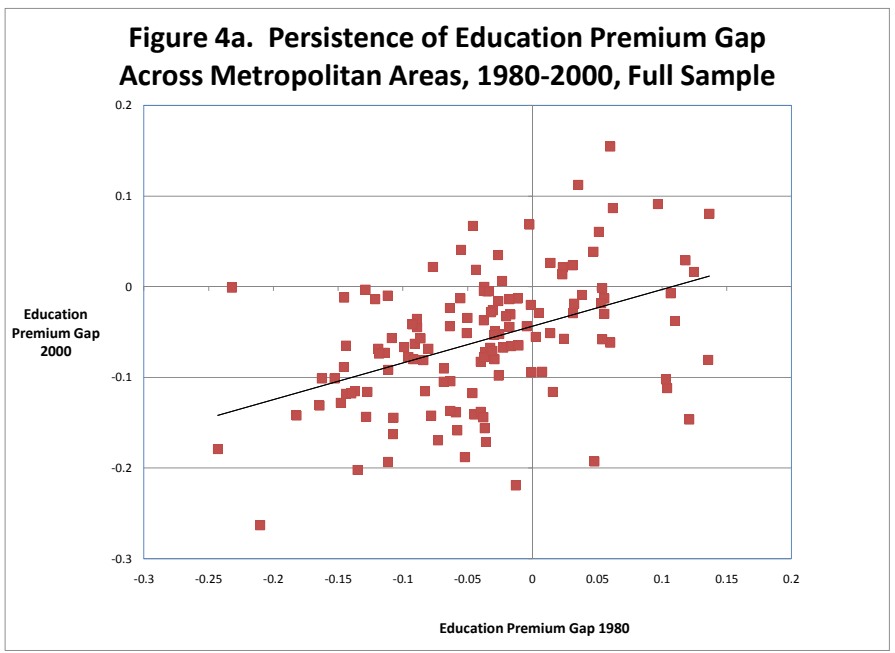

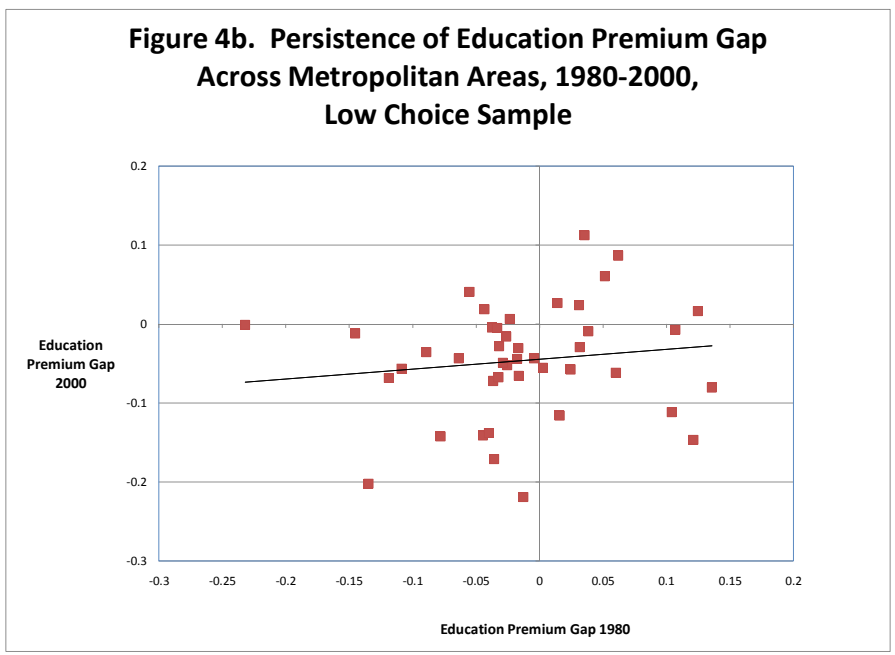


Figure 5. Effect of Log(Per Capita Taxes) on Log(Wage),By Income Percentile

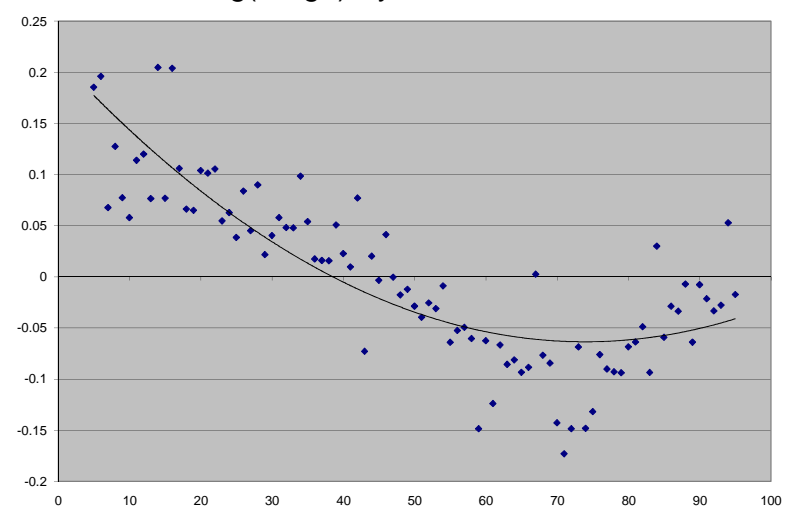

Figure 7. Effect of Log(Sales Tax PC) on Log(Wage), By Income Percentile

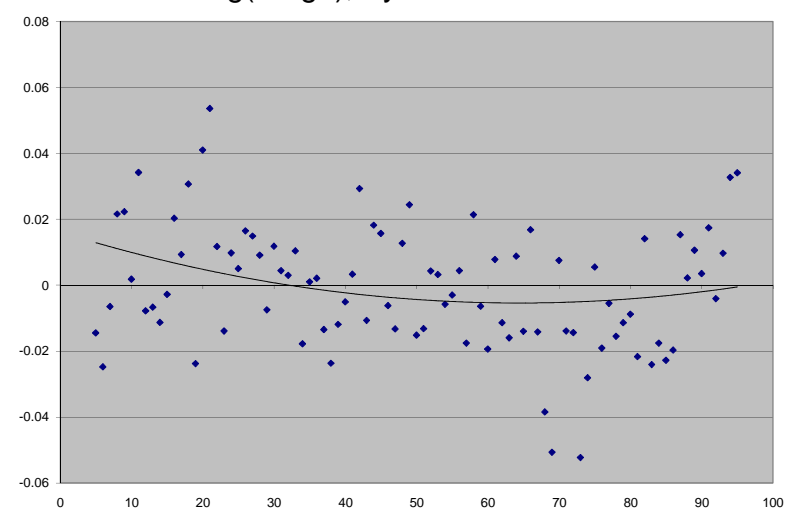

Figure 6. Effect of Log(Property Tax PC) on Log(Wage), By Income Percentile

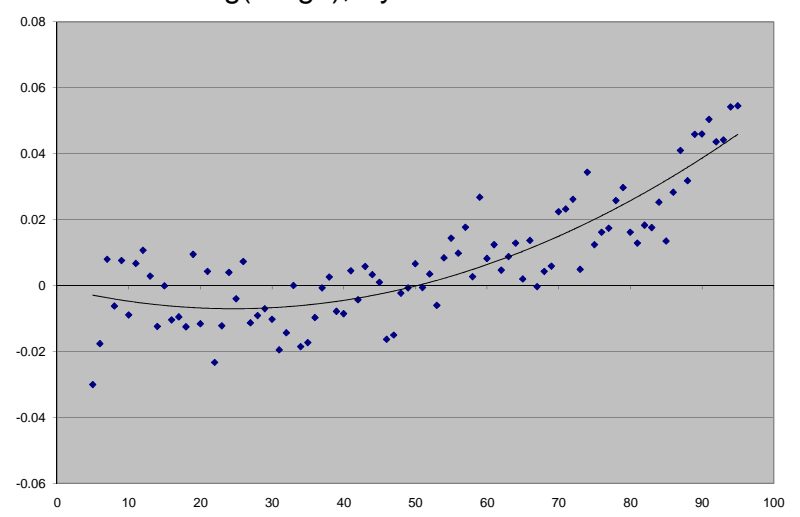

Figure 8. Effect of Log (User Fees and Charges PC) on Log(Wage), By Income Percentile

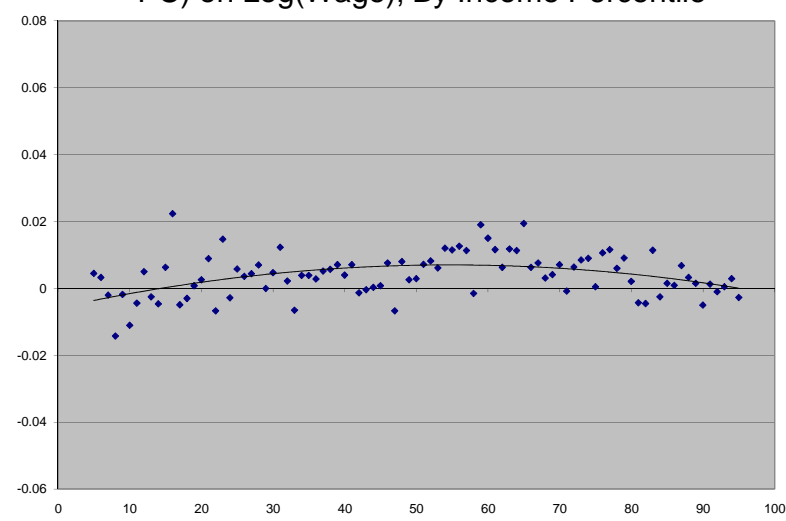

Figure 9. Effect of Log(Social Insurance Taxes PC) on Log(Wage), By Income Percentile

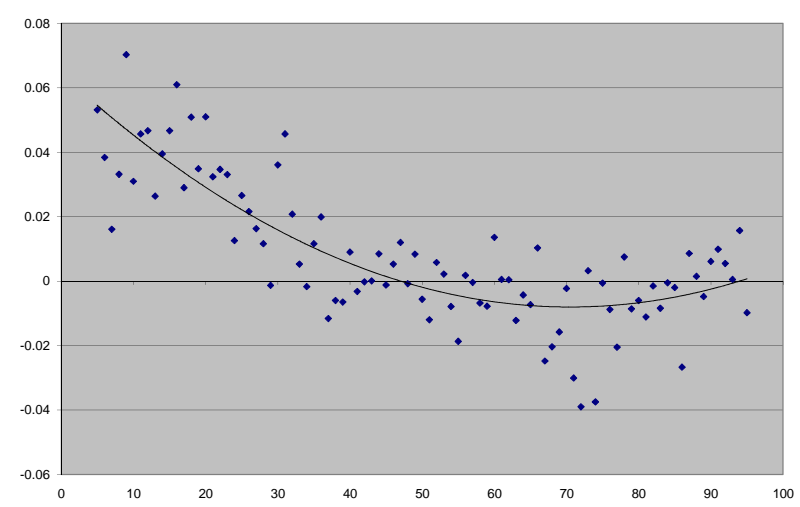

Figure 10. Effect of Log (Other Taxes PC) on Log(Wage), By Income Percentile

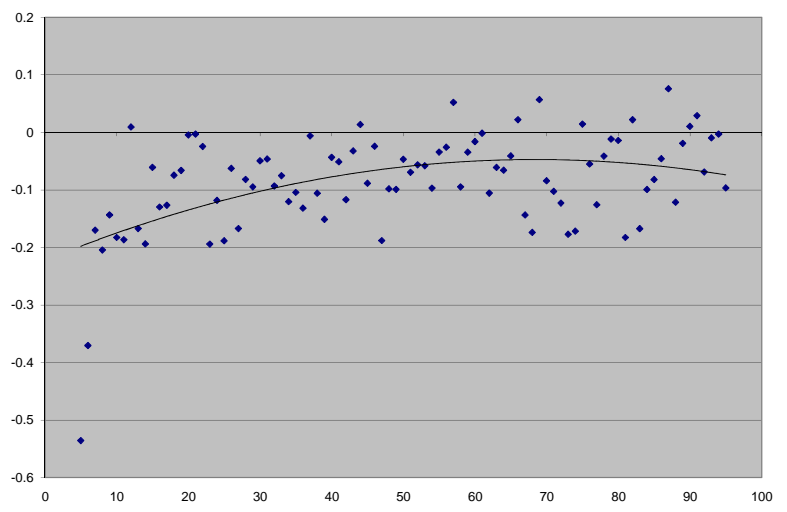


Figure 11. Effect of Log(Infrastructure Expenditure) on Log(Wage), By Income Percentile

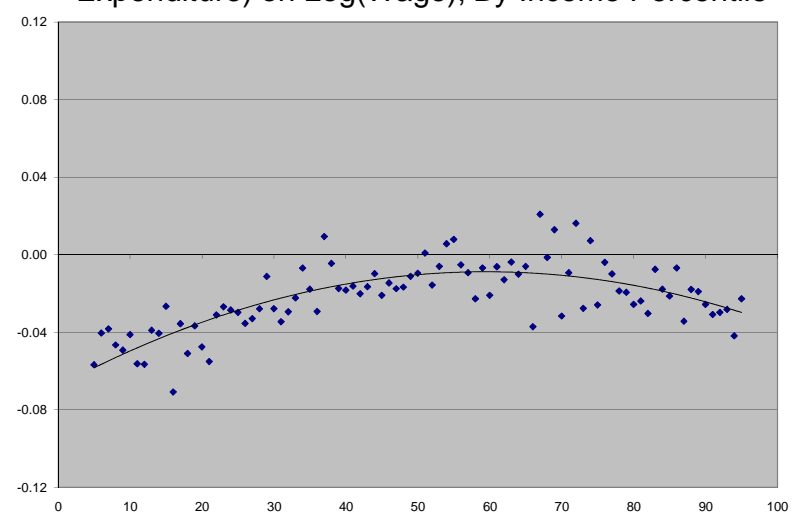

Figure 12. Effect of Log(Education Expenditure) on Log(Wage), By Income Percentile

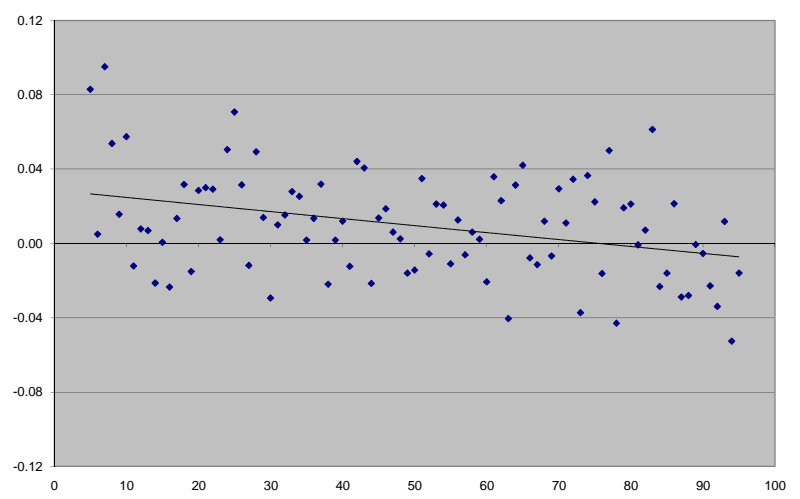

Figure 14. Effect of Log(Public Safety Expenditure) on Log(Wage), By Income Percentile

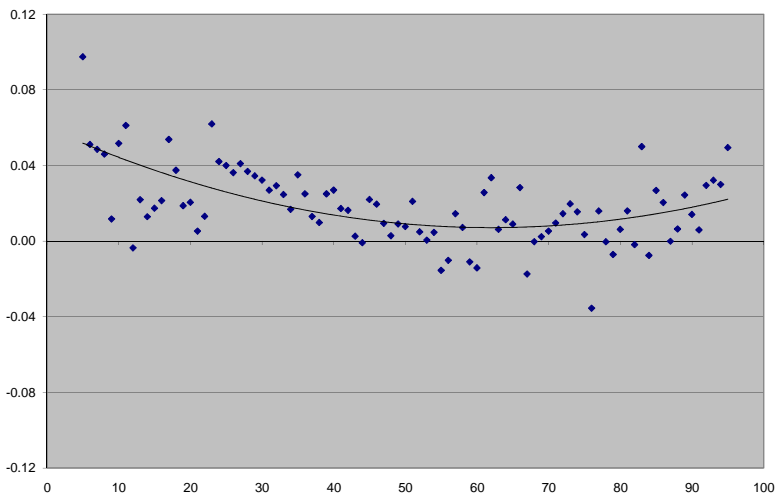

Figure 15. Effect of Log(Social Insurance Expenditure) on Log(Wage), By Income Percentile

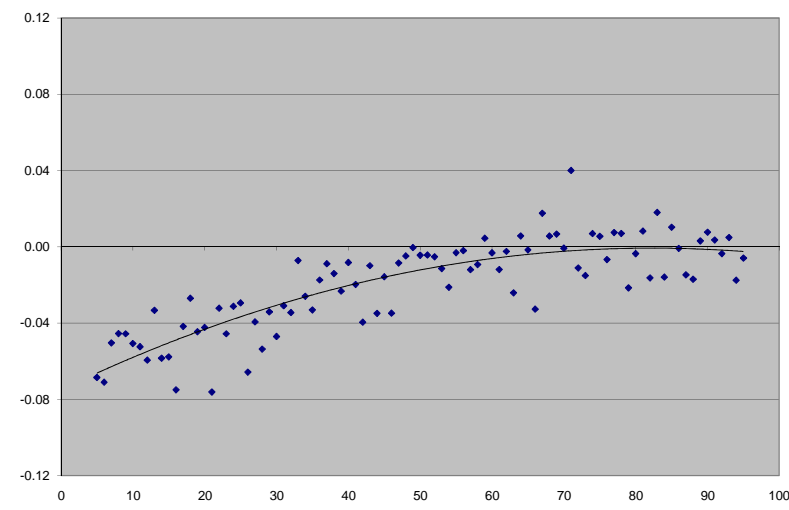

Figure 16. Effect of Log(Other Expenditure) on Log(Wage), By Income Percentile

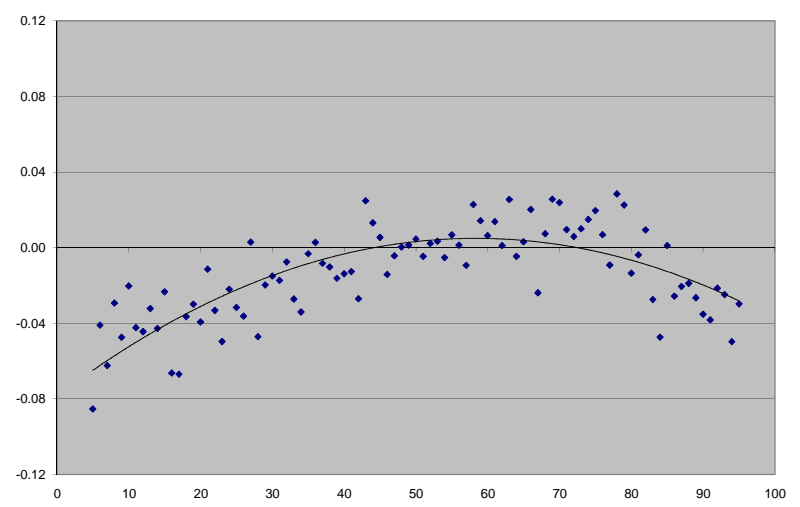

